\title{
Benchmarking Organic Micropollutants in Wastewater, Recycled Water and Drinking Water with In Vitro Bioassays
}

Beate I. Escher, ${ }^{* \dagger}{ }^{\dagger}$ Mayumi Allinson, ${ }^{\ddagger}{ }^{\S}$ Rolf Altenburger, $"$ Peter A. Bain, ${ }^{\perp}$ Patrick Balaguer, ${ }^{\#}$

Wibke Busch," Jordan Crago, ${ }^{\nabla}$ Nancy D. Denslow, ${ }^{\circ}$ Elke Dopp, Klara Hilscherova, ${ }^{\mathbb{}}$

Andrew R. Humpage, ${ }^{\text {is }}$ Anu Kumar, ${ }^{\perp}$ Marina Grimaldi, ${ }^{*}$ B. Sumith Jayasinghe, ${ }^{\bigcirc}$ Barbora Jarosova, ${ }^{\text {I }}$ Ai Jia, ${ }^{\square}$ Sergei Makarov, ${ }^{\square}$ Keith A. Maruya, ${ }^{\Phi}$ Alex Medvedev, ${ }^{\square}$ Alvine C. Mehinto, ${ }^{\Phi}$ Jamie E. Mendez,

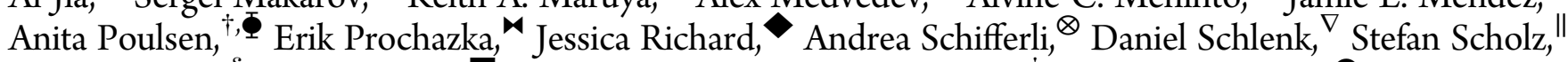
Fujio Shiraishi, ${ }^{\S}$ Shane Snyder, ${ }^{\square}$ Guanyong Su, ${ }^{\infty}$ Janet Y. M. Tang, ${ }^{\dagger}$ Bart van der Burg,

Sander C. van der Linden, ${ }^{\ominus}$ Inge Werner, ${ }^{\otimes}$ Sandy D. Westerheide, ${ }^{\infty}$ Chris K. C. Wong, Min Yang, ${ }^{\circledR}$ Bonnie H. Y. Yeung, Xiaowei Zhang, ${ }^{\infty}$ and Frederic D. L. Leusch ${ }^{\star}$

${ }^{\dagger}$ The University of Queensland, National Research Centre for Environmental Toxicology (Entox), 39 Kessels Rd, Brisbane, QLD 4108, Australia

${ }^{\ddagger}$ Centre for Aquatic Pollution Identification and Management (CAPIM), School of Chemistry, The University of Melbourne, 1-100 Grattan Street, Parkville, VIC 3010 Australia

${ }^{\S}$ National Institute for Environmental Studies, 16-2 Onogawa, Tsukuba 305-8506 Japan

"UFZ - Helmholtz Centre for Environmental Research, Department of Bioanalytical Ecotoxicology, Permoserstr. 15, 04318 Leipzig, Germany

${ }^{\perp}$ CSIRO Land and Water, Private Bag No. 2, Glen Osmond, SA 5064, Australia

\#Cancer Research Institute Montpellier, CRLC Val, d'Aurelle, Parc Euromédecine, 34298 Montpellier, Cedex 5, France

${ }^{\nabla}$ Aquatic Ecotoxicology, Department of Environmental Sciences, University of California, Riverside, Riverside, California 92521, United States

OUniversity of Florida, Department of Physiological Sciences, PO Box 110885, Gainesville, Florida 32611, United States

IWW Water Centre, Department of Toxicology, Moritzstrasse 26, 45476 Mülheim/Ruhr, Germany

${ }^{\mathbb{T}}$ Research Centre for Toxic Compounds in the Environment (RECETOX), Masaryk University, Kamenice 753/5, 62500, Brno, Czech Republic

¿4ustralian Water Quality Centre, 250 Victoria Square, Adelaide SA 5001, Australia

- University of Arizona, 1133 E. James E. Rogers Way, Harshbarger 108, Tucson, Arizona 85721-0011, United States

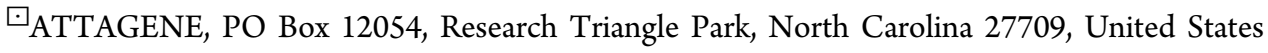

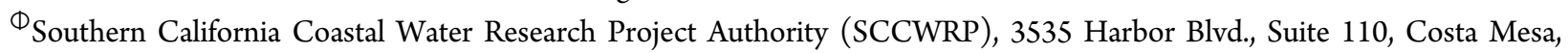
California 92626-1437, United States

Department of Cell Biology, Microbiology and Molecular Biology, University of South Florida, 4202 E Fowler Ave, ISA 2015, Tampa, Florida 33620, United States

${ }^{M_{S}}$ Smart Water Research Centre, Griffith University, Edmund Rice Dr, Griffith University Gold Coast Campus, Southport, QLD 4222, Australia

${ }^{\otimes}$ Swiss Centre for Applied Ecotoxicology, Eawag-EPFL, Überlandstr. 133, 8600 Dübendorf, Switzerland

${ }^{\infty}$ State Key Laboratory of Pollution Control and Resources Reuse, School of the Environment, Nanjing University, Nanjing 210046, PR China

๑BioDetection Systems, Science Park 406, 1098 XH, Amsterdam, The Netherlands

Department of Biology, Croucher Institute for Environmental Sciences, Level 10, Science Tower, Ho Sin Hang Campus, Hong Kong Baptist University, 224 Waterloo Rd. Kowloon Tong, Kowloon, Hong Kong

${ }^{\circledR}$ State Key Laboratory of Environmental Aquatic Chemistry, Research Center for Eco-Environmental Sciences, Chinese Academy of Sciences, PO Box 2871, Beijing 100085, PR China

Supporting Information 
ABSTRACT: Thousands of organic micropollutants and their transformation products occur in water. Although often present at low concentrations, individual compounds contribute to mixture effects. Cell-based bioassays that target health-relevant biological endpoints may therefore complement chemical analysis for water quality assessment. The objective of this study was to evaluate cell-based bioassays for their suitability to benchmark water quality and to assess efficacy of water treatment processes. The selected bioassays cover relevant steps in the toxicity pathways including induction of xenobiotic metabolism, specific and reactive modes of toxic action, activation of adaptive stress response pathways and system responses. Twenty laboratories applied 103 unique in vitro

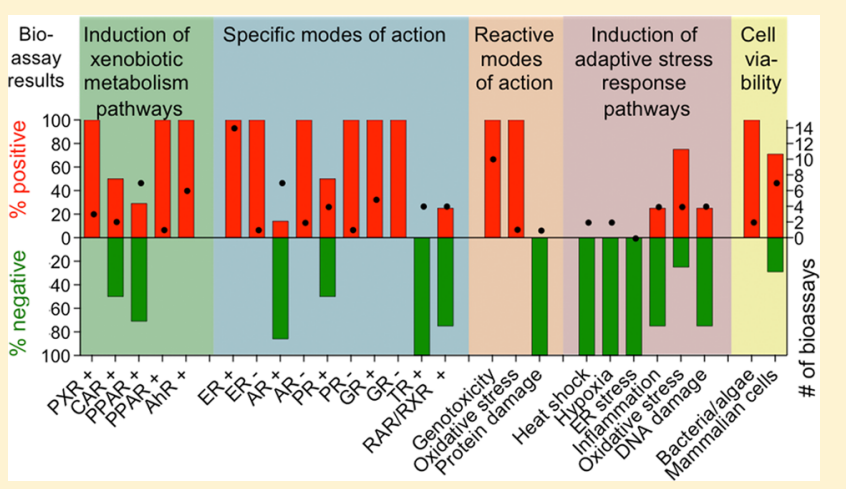
bioassays to a common set of 10 water samples collected in Australia, including wastewater treatment plant effluent, two types of recycled water (reverse osmosis and ozonation/activated carbon filtration), stormwater, surface water, and drinking water. Sixtyfive bioassays (63\%) showed positive results in at least one sample, typically in wastewater treatment plant effluent, and only five (5\%) were positive in the control (ultrapure water). Each water type had a characteristic bioanalytical profile with particular groups of toxicity pathways either consistently responsive or not responsive across test systems. The most responsive healthrelevant endpoints were related to xenobiotic metabolism (pregnane $\mathrm{X}$ and aryl hydrocarbon receptors), hormone-mediated modes of action (mainly related to the estrogen, glucocorticoid, and antiandrogen activities), reactive modes of action (genotoxicity) and adaptive stress response pathway (oxidative stress response). This study has demonstrated that selected cellbased bioassays are suitable to benchmark water quality and it is recommended to use a purpose-tailored panel of bioassays for routine monitoring.

\section{INTRODUCTION}

The Tox21, a joint program of the National Institutes of Health, U.S. Environmental Protection Agency (EPA), and U.S. Food and Drug Administration ${ }^{1}$ and the U.S. EPA ToxCast Program ${ }^{2}$ aim to advance molecular toxicology, systems biology, and computational toxicology to overcome shortcomings of traditional in vivo toxicity testing of chemicals. Parallel initiatives exist in Europe, for example, the EU project ChemScreen. ${ }^{3}$ Jointly these programs bring a paradigm shift in toxicity testing as in vitro methods help elucidate mechanisms of toxicity, prioritize chemicals for further testing and develop predictive models in order to refine, reduce, or replace future in vivo testing. These programs rely heavily on high-throughput screening (HTS) using cell-based and cell-free in vitro bioassays of large numbers of chemicals to elucidate their toxicity pathways. While Tox 21 focuses on the bioanalytical profiling of individual chemicals, these tools should also be applicable to environmental samples of unknown and complex composition, and this study brings together for the first time selected bioassays from Tox21 with established bioassays for water quality assessment. ${ }^{4}$

Cell-based bioassays have been developed to target all steps of the toxicity pathway (Figure 1). ${ }^{5}$ While the induction of xenobiotic metabolism may not lead to cytotoxicity, it is an indicator of the presence of pollutants. Some bioassays provide measures of mechanisms of toxicity by visualizing the interaction of stressors, for example, chemicals, with specific biological targets, for example, binding to endocrine receptors or reaction with DNA. The exposed cells may respond through induction of adaptive stress response pathways, a feature that can be used for the assessment of environmental pollutants, although it is not an adverse effect per se. Cell viability, growth and/or proliferation are indicators of adverse effects on a cellular level. If the cell represents a specialized tissue, this may give an indication of tissue-specific impairment.

Cellular responses will not always imply higher-level effects but are a prerequisite for whole organism and population responses. ${ }^{6}$ The direct detection of initiating key events in a

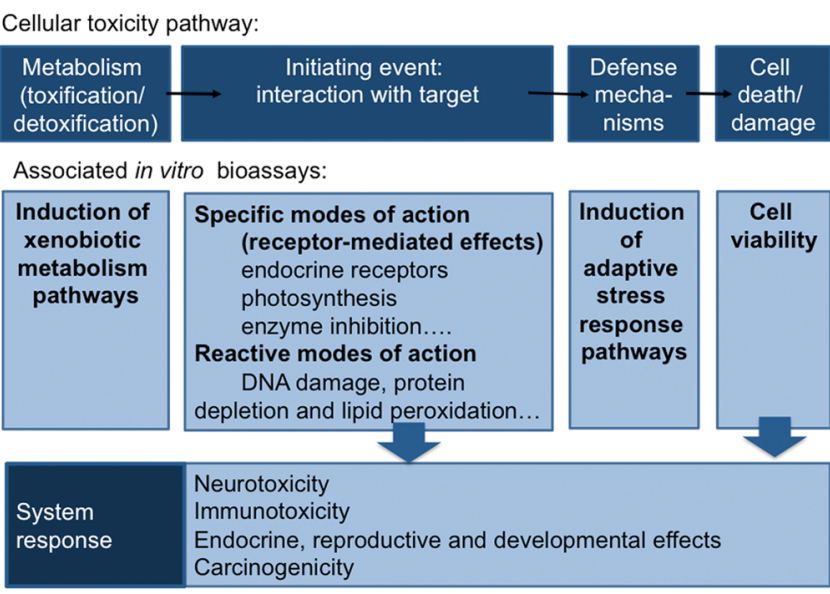

Figure 1. Classification of in vitro bioassays according to cellular toxicity pathways (adapted from refs 4,5 , and 117).

bioassay only provides a measure of a potential adverse effect because repair and defense mechanisms may ultimately prevent toxicity. From a precautionary perspective, however, the potential to cause an adverse effect is a crucial assessment endpoint. Cell-based bioassays are not suitable to replace regulatory in vivo tests but provide hazard information for screening and prioritization of chemicals. ${ }^{7}$

A large variety of cell-based bioassays have been applied for water quality assessment in the past ${ }^{4}$ but many of the end points evaluated under HTS toxicology programs ${ }^{8}$ are yet to be included. Many studies rely on a small set of bioassays and each study uses different types of water samples, sample preparation methods, bioassays, and data evaluation methods. Only a few cell-based bioassays have standardized protocols, such as the OECD or ISO guidelines. The goals of this study were to evaluate as many bioassays as practically achievable using one set of water samples with one sample preparation method and to recommend a screening test battery for water quality testing. 
We selected cell-based bioassays using three criteria. First, we selected bioassays that have previously been used for water quality assessment. Second, a comprehensive literature review allowed us to identify cell-based bioassays that responded to environmentally relevant organic micropollutants but had not been used for water quality assessment prior to this study. Third, for final selection of endpoints, we screened 25 nuclear receptors (NR) and 48 transcription factor (TF) response elements in HepG2 human liver carcinoma cell lines ${ }^{9}$ to ensure inclusion of endpoints relevant for the particular samples tested.

We evaluated 10 samples, including nine ambient water samples ranging from effluent, recycled water to drinking water, plus one procedural blank. The samples were extracted and concentrated with an optimized solid phase extraction (SPE) method and sent to a total of 20 worldwide laboratories applying 103 bioassays for bioanalytical testing. All experimental data were evaluated using a common method specifically developed for this study to harmonize the different approaches to data evaluation. The results were used not only to validate and compare the different bioassays for application with water samples but also to benchmark water quality. The data may also serve to compare the efficacy of different water treatment processes for removal of organic micropollutants.

It was not the goal of this study to directly compare bioassay protocols and performance of bioassays but rather to obtain an overview of the biological endpoints responsive to typical water contaminants. One goal was to cover the major health-relevant toxicity pathways introduced in Figure 1 and to evaluate which pathways were relevant for water quality testing. The study was further expected to identify the most robust and responsive bioassays, thus, not only mammalian but also bacterial assays were included. The outcome includes recommendations on the makeup of a screening test battery and on indicator bioassays that appear to be particularly relevant for further investigation in water quality monitoring programs.

\section{MATERIALS AND METHODS}

Samples. Ten grab samples of water were collected in December 2011 and January 2012 (Supporting Information (SI), Section S1 and Table S1). Sample Eff1 is a secondary treated sewage effluent (activated sludge treatment) that serves as influent to a Water Reclamation Plant (WRP) that produces high quality recycled water for indirect potable reuse. Three samples were taken at different stages of treatment: after microfiltration $(\mathrm{MF})$, reverse osmosis (RO) and advanced oxidation ( $\mathrm{AO}$ ) using $\mathrm{H}_{2} \mathrm{O}_{2}$ /UV. Bioanalytical assessments had been previously undertaken at this WRP. ${ }^{10,11}$

The second investigated WRP treats secondary sewage effluent (Eff2) by ozonation followed by biologically activated carbon filtration $\left(\mathrm{O}_{3} / \mathrm{BAC}\right)$ to produce recycled water for irrigation and industrial usage. The fate of micropollutants in this plant has been previously characterized in more detail. ${ }^{12-14}$

River water (RW) and drinking water (DW) samples were collected at the inlet and outlet of a metropolitan drinking water treatment plant applying chlorination and chloramination, which was also previously assessed with bioanalytical tools. ${ }^{10,15}$

The stormwater sample (SW) was collected from a stormwater drain in Brisbane, Australia, that receives runoff from a residential catchment. ${ }^{16}$ The laboratory blank consisted of ultrapure water (Milli-Q water) run through the same SPE process as the samples. Fourteen liters were collected for each of Eff1, MF, Eff2, and SW, while $28 \mathrm{~L}$ were collected for the remaining samples.
Sample Preparation and Distribution to the Participating Laboratories. The SPE was performed according to Macova et al. ${ }^{10}$ using the sorbent materials Oasis HLB (Waters) followed by Supelclean coconut charcoal (Sigma-Aldrich), a combination that was confirmed previously to extract a broad range of organic micropollutants. ${ }^{17}$ Details and information on sample preparation and the logistics of sample distribution are summarized in the SI, Section S1. All distributed samples were labeled with codes for blind sample processing.

Sample Characterization. 293 organic micropollutants were previously characterized in these samples. ${ }^{18}$ Dissolved organic carbon concentrations are reported in the SI, Table S1.

Bioassays. The majority of selected bioassays was based on mammalian, bacterial or yeast cells. A zebrafish embryo test was included because fish embryos are considered as nonprotected life stages and as ethically accepted alternative to the testing of (adult) animals. ${ }^{19}$ Only one bioassay employed a naked enzyme (acetylcholinesterase inhibition assay).

All applied bioassays and their associated experimental methods are listed in Table 1 and categorized according to the toxicity pathways outlined in Figure 1. For bioassays where the protocol was modified or applied for the first time, Section S2 in the SI and Table S2 give additional information on the experimental procedures.

Concentration-Effect Assessment. A critical aspect when working with diverse biological endpoints is a consistent data evaluation process. It was the goal of the present study to harmonize the data evaluation as much as possible, which is challenging given the different types of endpoints measured but a prerequisite for quantitative comparison between different bioassays.

The concentrations of samples were expressed in units of relative enrichment factor REF. The REF is the product of the enrichment factor of the SPE process and the dilution of the extract in the bioassay (for derivation of equations, see SI, Section S3). A REF > 1 means that the sample is enriched in the bioassay (e.g., a REF of 10 means the sample was concentrated 10 -fold in the bioassay), a REF $<1$ means it was diluted in the bioassay, and a REF of 1 is equivalent to the organic micropollutants in the ambient (undiluted and unconcentrated) sample stripped from inorganics, metals and most colloidal organic matter by SPE.

For each bioassay, the measured responses were plotted against the sample concentration expressed as REF (Figure 2). For assays with a known maximum response, responses were converted to percent of maximum effect. For all endpoints that relate to cell viability and cell population growth, the controls can be expressed as $0 \%$ effect, while $100 \%$ relates to "no growth" or "all cells dead". For reporter gene assays that measure the binding to a receptor or the transactivation of a receptor, $0 \%$ refers to the basal activity of the receptor, while $100 \%$ is defined using an appropriate reference compound that can saturate the receptor without causing cytotoxicity.

The ideal case would be a full concentration-effect curve covering $0 \%$ to $100 \%$ of effect (Figure $2 \mathrm{~A}$ ), which typically has a sigmoidal shape that can be described with a log-logistic equation. Any log-logistic concentration-effect curve will be linear with respect to (nonlogarithmic) concentrations at low effect level (up to $20-30 \%$ effect). As the water samples investigated in the present study often showed only very low effect levels, the linear form of the concentration-effect curves was used for derivation of the effect concentration causing $10 \%$ of maximum effect $\left(\mathrm{EC}_{10}\right)$ of the samples 
Table 1. Bioassays Used and Their Toxicity Pathway Classifications ${ }^{a}$

\begin{tabular}{|c|c|c|c|c|}
\hline$\#$ & laboratory & bioassay & $\begin{array}{l}\text { literature reference for } \\
\text { method development }\end{array}$ & $\begin{array}{l}\text { experimental approach } \\
\text { (literature reference/more information in SI) }\end{array}$ \\
\hline \multicolumn{5}{|c|}{ Xenobiotic Metabolism } \\
\hline 1 & ATG & PXR-cisFACTORIAL & 46 & 9 \\
\hline 2 & ATG & PXR-transFACTORIAL & 46 & 9 \\
\hline 3 & IRCM & HG5LN PXR & 47 & 48 \\
\hline 4 & ATG & CAR-transFACTORIAL & 46 & 9 \\
\hline 5 & CAPIM & CAR-yeast & 49 & see SI, Section S2-A. \\
\hline 6 & ATG & $\operatorname{PPAR} \alpha$-transFACTORIAL & 46 & 9 \\
\hline 7 & ATG & PPAR $\gamma$-transFACTORIAL & 46 & 9 \\
\hline 8 & IRCM & HELN-PPAR $\gamma$ & 50 & 28 \\
\hline 9 & BDS & CALUX-PPAR $\alpha$ & 51 & 52 \\
\hline 10 & BDS, CSIRO & CALUX-PPAR $\gamma 2$ & 53 & 52 \\
\hline 11 & $\mathrm{HK}$ & MCF7-PPAR & 54 & 54 \\
\hline 12 & GU & PPAR $\gamma$-GeneBLAzer & 27 & 55 \\
\hline 13 & GU & Anti-PPAR $\gamma$-GeneBLAzer & 27 & see SI, Section S2-B. \\
\hline 14 & CAPIM & AhR-yeast & 56 & 57 and SI, Section S2-B. \\
\hline 15 & UQ, RECETOX & CAFLUX & 58 & RECETOX: 59 UQ: 60 \\
\hline 16 & RECETOX & H4IIEluc & 61 & 59 \\
\hline 17 & $\mathrm{HK}$ & MCF7DRE & 54 & 54 \\
\hline 18 & ATG & AhR-cisFACTORIAL & 46 & 9 \\
\hline 19 & UFZ & DART cyp1a induction & 62 & 63 \\
\hline \multicolumn{5}{|c|}{ Specific Modes of Action } \\
\hline 20 & UQ, SWISS & algae photosynthesis inhibition & 31 & 64 \\
\hline 21 & UQ & acetylcholinesterase inhibition & 65 & 30 \\
\hline \multicolumn{5}{|c|}{ Specific MOA: ER } \\
\hline 22 & GU, CSIRO, BDS, IWW & ER-CALUX & 66 & 33 \\
\hline 23 & UQ & E-SCREEN & 67 & 10 \\
\hline 24 & SWISS, CSIRO, UA & YES & 68 & 69 \\
\hline 25 & CAPIM & hER yeast & 49 & 70 \\
\hline 26 & CAPIM & medER yeast & 49 & 70 \\
\hline 27 & IRCM & HELN-ER $\alpha$ & 71 & 72 \\
\hline 28 & IRCM & HELN-ERß & 71 & 73 \\
\hline 29 & ATG & ERE-cisFACTORIAL & 46 & 9 \\
\hline 30 & RECETOX & hER $\alpha$-HeLa-9903 & 74 & 74 \\
\hline 31 & HK & MCF7-ERE & 54 & 54 \\
\hline 32 & ATG & ER $\alpha$-transFACTORIAL & 46 & 9 \\
\hline 33 & NJU & Steroidogenesis (estrogens) & 75 & 76 \\
\hline 34 & UFZ & DART cyp19alb & 77 & 63 \\
\hline 35 & UF, USF, UCR, SCCWRP & ER $\alpha$-GeneBLAzer & 27 & 55 see SI, Section S2-C. \\
\hline 36 & CSIRO, GU & Anti ER-CALUX & 66 & 17 \\
\hline \multicolumn{5}{|c|}{ Specific MOA: AR } \\
\hline 37 & GU, BDS, CSIRO & AR-CALUX & 66,78 & 33 \\
\hline 38 & IRCM & HELN-AR & 79 & 80 \\
\hline 39 & $\mathrm{HK}$ & MCF7-ARE & 54 & 54 \\
\hline 40 & UA, CSIRO & YAS & 81 & 82 \\
\hline 41 & UF, USF, UCR, SCCWRP & AR-GeneBLAzer & 27 & 55 see SI, Section S2-C. \\
\hline 42 & ATG & AR-transFACTORIAL & 46 & 9 \\
\hline 43 & RECETOX & MDA-kb2 & 83 & 84 \\
\hline 44 & RECETOX & Anti-MDA-kb2 & 83 & 84 \\
\hline 45 & CSIRO, GU & Anti-AR-CALUX & 66,78 & 17 \\
\hline \multicolumn{5}{|c|}{ Specific MOA: GR } \\
\hline 46 & GU, BDS, CSIRO & GR-CALUX & 66 & 33 \\
\hline 47 & UA & GR Switchgear & & see SI, Section S2-D. \\
\hline 48 & ATG & GR-transFACTORIAL & 46 & 9 \\
\hline 49 & RECETOX & GR-MDA-kb2 & 83 & 84 \\
\hline 50 & GU, UF, USF, SCCWRP & GR-GeneBLAzer & 27 & 55 \\
\hline 51 & GU & Anti-GR-GeneBLAzer & 27 & \\
\hline 52 & GU & Anti-GR-CALUX & 66 & 33 \\
\hline \multicolumn{5}{|c|}{ Specific MOA: PR } \\
\hline 53 & UF, USF, UCR, SCCWRP & PR-GeneBLAzer & 27 & 55 see SI, Section S2-B. \\
\hline 54 & GU, BDS, CSIRO & PR-CALUX & 66 & 33 \\
\hline
\end{tabular}


Table 1. continued

\begin{tabular}{|c|c|c|c|c|}
\hline$\#$ & laboratory & bioassay & $\begin{array}{l}\text { literature reference for } \\
\text { method development }\end{array}$ & $\begin{array}{c}\text { experimental approach } \\
\text { (literature reference/more information in SI) }\end{array}$ \\
\hline \multicolumn{5}{|c|}{ Specific MOA: PR } \\
\hline 55 & GU & Anti-PR-CALUX & 66 & \\
\hline 56 & NJU & steroidogenesis (progesterone) & 75 & 76 \\
\hline 57 & NJU & steroidogenesis (17 $\alpha \mathrm{OH}$-progesterone $)$ & 75 & 76 \\
\hline \multicolumn{5}{|c|}{ Specific MOA: TR } \\
\hline 58 & BDS, GU & TR-CALUX & 66 & 17 \\
\hline 59 & UQ & T-SCREEN & 85 & \\
\hline 60 & ATG & THR $\alpha 1$-transFACTORIAL & 46 & 9 \\
\hline 61 & IRCM & HELN-TR & & 86 \\
\hline \multicolumn{5}{|c|}{ Specific MOA: Reproductive and Developmental Effects } \\
\hline 62 & HK & MCF7-RARE & 54 & 54 \\
\hline 63 & UQ & P19/A15 & 87 & see SI, Section S2-E. \\
\hline 64 & ATG & RORß-transFACTORIAL & 46 & 9 \\
\hline 65 & CAPIM & hRAR-Yeast Assay & 49 & 88 \\
\hline \multicolumn{5}{|c|}{ Reactive MOA } \\
\hline 66 & UQ, RCEES & umuC TA1535/pSK1002 & 89 & UQ: 90 RCEES: 89 \\
\hline 67 & UQ & umuC TA1535/pSK1002 +S9 & 89 & 90 \\
\hline 68 & RCEES & umuC NM5004 & 91 & 89 \\
\hline 69 & RECETOX & SOS chromotest & 92 & 93 \\
\hline 70 & UA, IWW & Ames TA98 & 94 & IWW: 95 \\
\hline 71 & UA, IWW & Ames TA98+ S9 & 94 & IWW: 95,96 \\
\hline 72 & UA & Ames TAmix & 94 & \\
\hline 73 & UA & Ames TAmix $+S 9$ & 94 & \\
\hline 74 & UQ IWW & Ames TA100 & 94 & UQ: 97 IWW: 95 \\
\hline 75 & AWQC & micronucleus assay & 98 & 99 \\
\hline 76 & CSIRO & ROS formation RTG2 & 100 & 101 \\
\hline 77 & UQ & protein damage E.coli & 102 & 38 \\
\hline \multicolumn{5}{|c|}{ Adaptive Stress Response } \\
\hline 78 & ATG & HSE-cisFACTORIAL & 46 & 9 \\
\hline 79 & UFZ & hspb11 induction DART & 63 & 63 \\
\hline 80 & ATG & HIF-1a-cisFACTORIAL & 46 & 9 \\
\hline 81 & UA & Hypoxia-Switchgear & & see SI, Section S2-F. \\
\hline 82 & ATG & NF-kB-cisFACTORIAL & 46 & 9 \\
\hline 83 & UQ & NF-kB-Geneblazer & 27 & 55 see SI, Section S2-C. \\
\hline 84 & BDS & NF-kB-CALUX & 103 & 33 \\
\hline 85 & GU & Jurkat E6.1 IkB & none & see SI, Section S2-G. \\
\hline 86 & UQ & AREc32 & 104 & 39 \\
\hline 87 & UA & Nrf2-keap & 105 & see SI, Section S2-H. \\
\hline 88 & ATG & Nrf2/ARE-cisFACTORIAL & 46 & 9 \\
\hline 89 & BDS & Nrf2-CALUX & 106 & 52 \\
\hline 90 & ATG & p53-cisFACTORIAL & 46 & 9 \\
\hline 91 & BDS & p53-CALUX & 106 & 52 \\
\hline 92 & BDS & p53-CALUX +S9 & 106 & 52 \\
\hline 93 & UF & p53-GeneBLAzer & 27 & 55 see SI, Section S2-C. \\
\hline \multicolumn{5}{|c|}{ Cytotoxicity and Indicators of System Response } \\
\hline 94 & UQ & AREc32 cell viability & 39 & 39 \\
\hline 95 & GU & Caco 2 NRU & 107 & 17 see SI, Section S2-I. \\
\hline 96 & CSIRO & RTG2MTT & 108 & \\
\hline 97 & UFZ & DART 48h lethality & 109 & 110 \\
\hline 98 & UFZ & DART $120 \mathrm{~h}$ sublethal & 111 & 110 \\
\hline 99 & GU & SK-N-SH cytotoxicity & 112 & see SI, Section S2-J. \\
\hline 100 & GU & THP1 cytokine & 113 & 17 see SI, Section S2-K. \\
\hline 101 & UQ & algae growth inhibition & 114 & 64 \\
\hline 102 & UQ, SWISS & Vibrio fischeri (Microtox) & 115 & SWISS: 69 UQ: 18 \\
\hline 103 & RCEES & Photobacterium phosphoreum & 116 & \\
\hline
\end{tabular}

${ }^{a}$ Assay numbers (\#) are equivalent to the numbers in Figure 3. Literature references are provided for the method development and for how the assay was performed. Modifications of the assay methods are summarized in the Supporting Information, SI, Table S2.

(Figure 2C). A detailed derivation of $\mathrm{EC}_{10}$ is provided in the SI, Section S3-A.
For assays where the maximum response was unknown or unachievable, the responses were normalized to growth medium 
Bioassays where maximum of effect can be quantified

(cytoxicity, hormone receptors, xenobiotic metabolism):

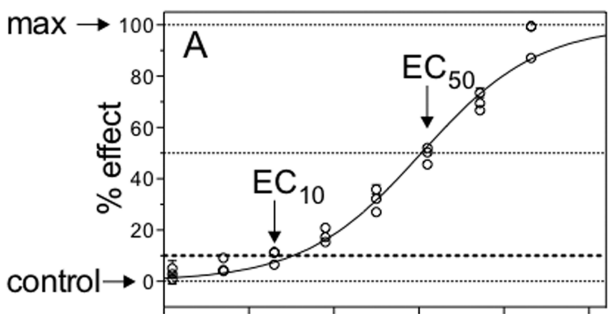

log concentration (REF)

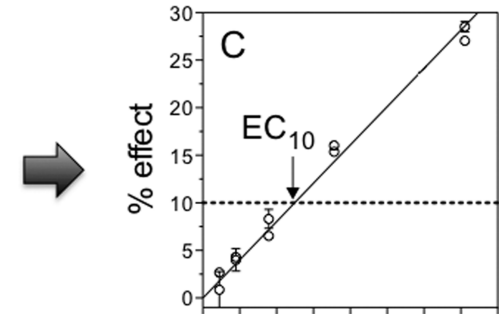

concentration (REF)

Bioassays where no maximum of effect can be reached

(due to nature of endpoint, e.g., genotoxicity, or cytotoxicity interference):
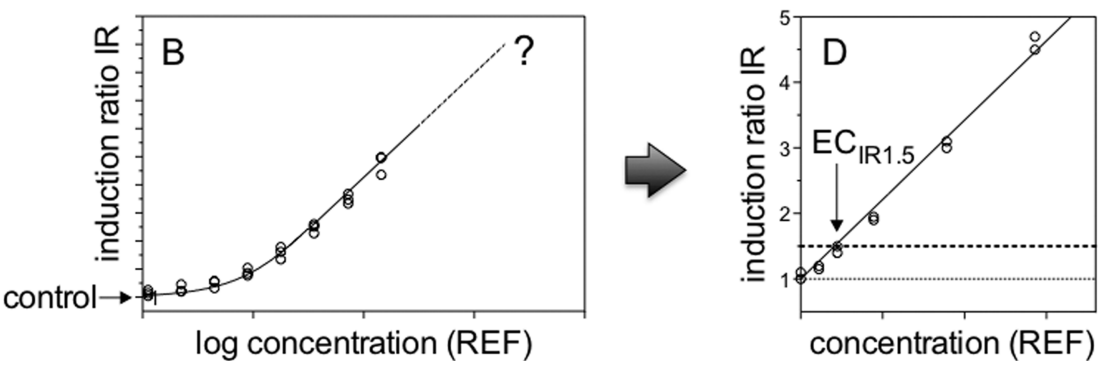

Figure 2. Overview of the concentration-effect models applied to derive benchmark effect concentrations (EC).

controls (including the same percentage of solvent as in the corresponding samples) and assessed via the induction ratio (IR; that is, fold induction relative to control). The maximum response was unknown if no appropriate reference compound existed, or if cytotoxicity quenched the reading of the reporter activity. The problem also arose if the endpoint is inducible or, by nature, there is no clear upper limit, for example, for DNA damage or adaptive stress response. In practice, linear regression through the control effect level $(I R=1)$ was used for derivation of the effect concentration that causes an IR of 1.5, or $\mathrm{EC}_{\mathrm{IR} 1.5}$ (Figure 2D). A detailed derivation of $\mathrm{EC}_{\mathrm{IR} 1.5}$ is provided in the SI, Section S3-B together with a discussion of the comparability of $\mathrm{EC}_{10}$ versus $\mathrm{EC}_{\mathrm{IR} 1.5}$ (SI Table S3).

A bioassay can be run in antagonistic mode if the receptors are occupied with a constant concentration of a known and potent agonist. Varying concentrations of sample are added and if the signal of the control is suppressed the sample can be considered to exhibit an antagonistic effect. The effect concentration causing a suppression ratio $\mathrm{SR}$ of $0.2, \mathrm{EC}_{\mathrm{SR} 0.2}$, was used to describe all antagonistic effects and correspondingly an $\mathrm{EC}_{\mathrm{CD} 0.2}$ was defined for endpoints that are based on chaperone dissociation (e.g., I $\kappa \mathrm{B}$ dissociation from $\mathrm{NF} \kappa \mathrm{B}$ ). A detailed derivation is provided in the SI, Section S3-C and Figure S1.

Data Presentation. A heatmap presenting all measured EC values was generated using the $\mathrm{R}$ Software package gplots (www.r-project.org/). Hierarchical clustering was performed using the "complete linkage" method to find similar clusters of water samples.

\section{RESULTS}

Repeatability of Bioassays. A number of bioassays were performed simultaneously in multiple laboratories. As discussed in detail in the SI, Section S4 and Table S4, the results were consistent between laboratories and therefore the results of the same bioassays were averaged.
Initial Screening of Nuclear Receptors and Transcription Factors. The FACTORIAL bioassays ${ }^{9}$ were used for an initial profiling of the water samples after enrichment by SPE to a REF of 4. As discussed in the SI, Section S5 and Figure S2, an IR of 1.5 is regarded as the threshold for positive effects. In the SI, Figure S3, the activity profiles of all samples are depicted.

The blank did not induce any of the tested endpoints indicating that the sample extraction and enrichment process did not negatively influence the test outcome. The Eff1 and Eff2 samples caused an activation of five of 25 nuclear receptors (NR) and 5 of 48 transcription factors (TF) tested (SI Figure $\mathrm{S} 3 \mathrm{~A}$ and $\mathrm{C}$ ). The active NRs were the pregnane $\mathrm{X}$ receptor (PXR), the peroxisome proliferator-activated receptor (PPAR $\gamma$ ), the estrogen receptor $(\mathrm{ER} \alpha)$ and marginally the glucocorticoid receptor (GR) and the liver X receptor (LXR). The active TFs were related to the aryl hydrocarbon receptor (AhR), PXR, the oxidative stress response (nrf2/ARE), the estrogen response element (ERE), and the RAR-related orphan receptor (RORE).

The screening provides strong support to expand the test battery to include additional endpoints to those routinely employed. ${ }^{4}$ Particularly the PXR and AhR, which are related to xenobiotic metabolism, warrant more attention as these had the highest activity in the prescreening assay. The LXR is relevant as its activation induces the PPAR ${ }^{20}$ The PPAR pathway is related to obesity $^{21}$ and has gained much attention in recent years and therefore various PPAR-related endpoints have been included in the test battery if not specifically LXR. The oxidative stress response pathway appeared to be of high relevance and has rarely been investigated with water samples prior to this study.

In response to the findings of this screening, the active three NRs and five TFs and two others associated to relevant pathways (CAR, $\operatorname{PPAR} \alpha, \mathrm{AR}, \mathrm{GR}, \mathrm{THR} \alpha 1$, ROR $\beta$, HSE, HIF1a, NF $\kappa \mathrm{B}, \mathrm{p} 53$ ) were included in the detailed dose-response analysis.

Responsiveness of the Bioassays. Figure 3, Table 2, and Table S5 in the SI give an overview of all results of the 101 different bioassays tested plus the two bacterial cytotoxicity assays. 


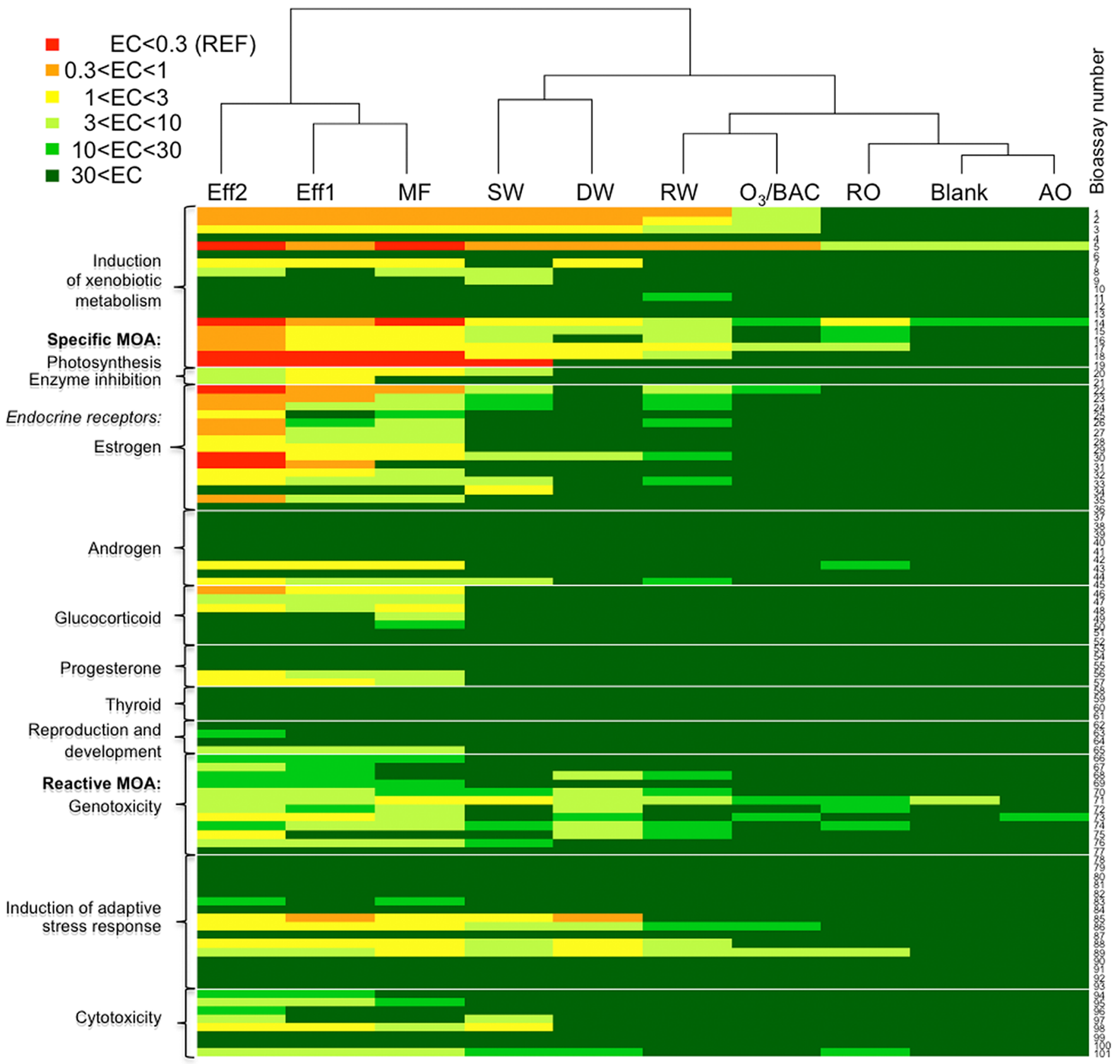

Figure 3. Summary of results in 101 bioassays (excluding inactive FACTORIAL and the bacterial cytotoxicity assays). Plotted are the effect concentrations $\left(\mathrm{EC}_{10}, \mathrm{EC}_{\mathrm{IR} 1.5}\right.$, or $\left.\mathrm{EC}_{\mathrm{SR} 0.2}\right)$ in units of $\mathrm{REF}$ (relative enrichment factors). The colors encode for the magnitude of the EC. Green stands for high effect concentrations (low potency) and transitions to red for low effect concentrations (high potency). Dark green are EC values that were $>30 \mathrm{REF}$ (which means that the sample that is enriched 30 times still does not show an effect), green from 10 to 30 REF, light green from 3 to 10 REF. A sample that has its EC at concentrations of the native sample up to three times enriched is denoted in yellow. Samples that have to be diluted for the EC are orange for up to 3 times diluted (REF 1 to 0.3 ) and red for over 3 times diluted. Numbers on the right refer to bioassay numbers in Table 1 .

A positive response is defined here as $\mathrm{EC}_{\mathrm{IR} 1.5}$ or $\mathrm{EC}_{10}$ lower than the highest tested REF, thus no extrapolations were performed.

The first two questions that we have to answer to judge the suitability of bioassays for water quality assessment are (A) "do "polluted" samples induce a response?" and (B) "is the response acceptably low in control samples?” (A) Sixty-five bioassays showed a response in at least one of the water samples. For Eff2, which can be considered as a moderately "polluted" sample, the number of positive results was 60. (B) No solvent blank caused any effect and the procedural blank with ultrapure water only produced effect in five bioassays (4.9\%).
Procedural Blank. Even small impurities leaching out of the material or present in the solvent would likely contribute to the nonspecific effect of the blank. Here we applied two different SPE sorbent materials (HLB and coconut charcoal), which were eluted separately and required twice the amount of solvent. This consideration rationalizes the low but positive results of the blanks in the two bioluminescence inhibition assays with marine luminescent bacteria, which were higher than previously seen when only one type of solid-phase material were applied. ${ }^{10}$

Furthermore, the yeast-based assays AhR-yeast and CAR-yeast showed responses in the blanks but only at much higher REF 

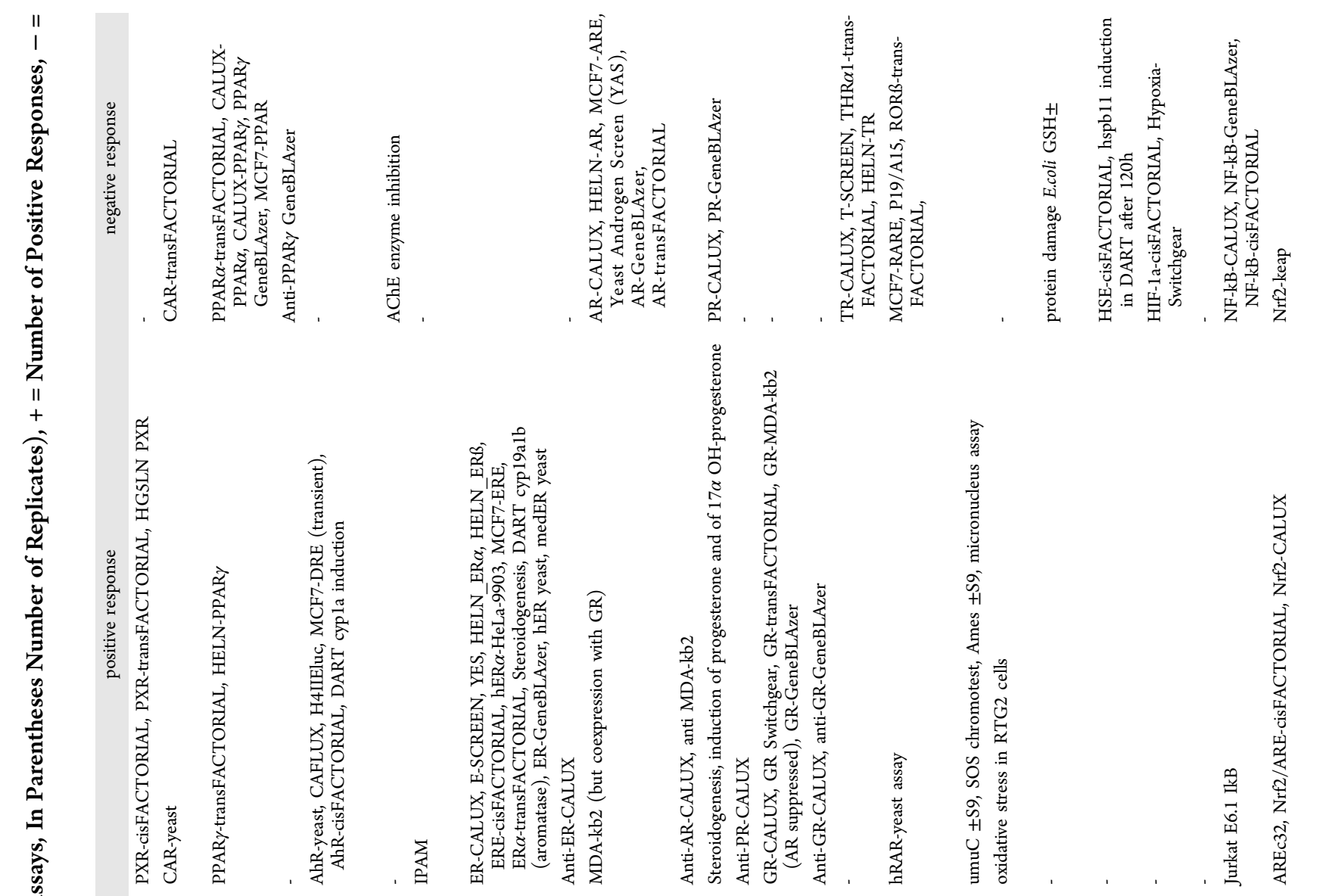

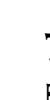

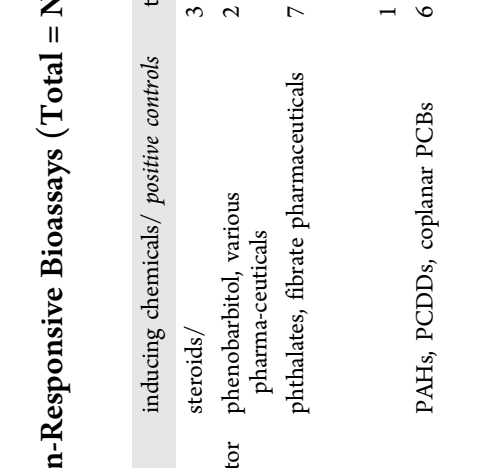

产

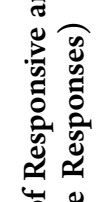

nmental Science \& Technology

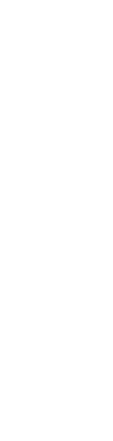




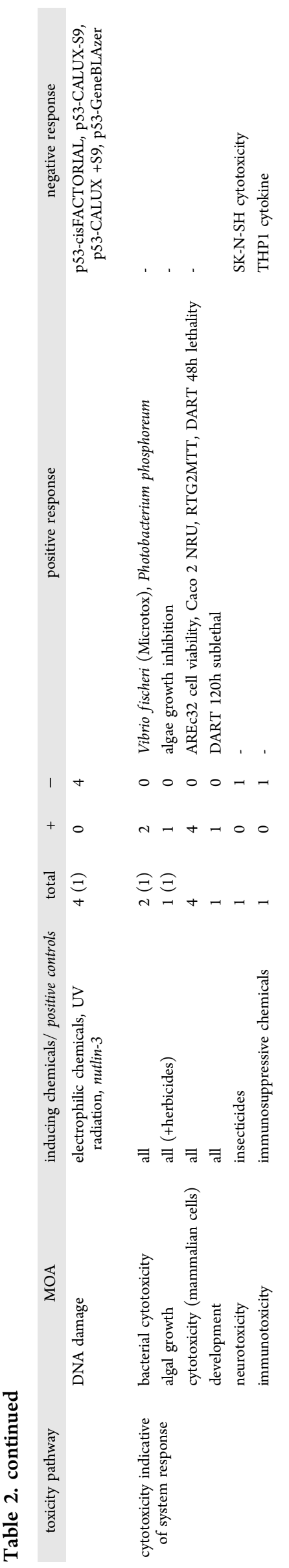

than the samples. A positive blank value was observed in one of the various Ames assays and is most likely due to measurement uncertainty as this value was derived from only one data point.

Bacterial Cytotoxicity Screening Assays. The bacterial cytotoxicity assays with Vibrio fischeri and Photobacterium phosphoreum were used as quick bioanalytical assessment tools, as these tests are rapid with only $15-30 \mathrm{~min}$ of exposure. Bioluminescence tests are nonspecific assays, as all stressors can impair the energy production and thus decrease bioluminescence. They provide a high responsiveness, that is, often the indicate effects for the "diluted" sample at REFs of less than 1 . However, the high sensitivity if compared to other cellular assays may result from a higher bioavailability, that is, absence of serum proteins typically used in in vitro assay. This increased bioavailability could result in a detection of trace amounts of coextracted dissolved organic carbon (DOC). In particular the low-molecular fraction of assimilable organic carbon can add to the observed effects as previously demonstrated. ${ }^{22}$ However, the high sensitivity may also result from specific interactions with bacterial physiology. Therefore, and because the control sample exhibited some effects as well, the luminescence assays have been excluded from the heatmap (see below).

Heatmap. The summary of $101 \mathrm{EC}$ values (excluding the two bacterial cytotoxicity assays) in each of the 10 samples is presented in form of a heatmap (Figure 3, data summarized in SI, Table S5). The similarity of bioanalytical fingerprints between different water samples was characterized by hierarchical clustering.

Evidently, quantitative comparison is difficult because EC were expressed as $\mathrm{EC}_{10}$ or $\mathrm{EC}_{\mathrm{IR} 1.5}$ and these two values are only directly comparable if the maximum IR is around 6 (see discussion in SI, Section S3-B). Therefore hierarchical clustering was only performed on samples and not on bioassays.

The closest similarity existed between the blank and the highly treated AO sample, while the RO sample clustered with this group on the next level of hierarchy (Figure 3). Surface water and ozonated recycled water clustered together. Both of these groups (cluster $\mathrm{RW}+\mathrm{O}_{3} / \mathrm{BAC}$ and cluster $\mathrm{RO}+\mathrm{Blank}+\mathrm{AO}$ ) clustered closely on the next level of similarity. Of the more polluted samples, Effl and MF were highly similar. This is not unexpected, as microfiltration, the only treatment step separating the two samples, is ineffective at removing micropollutants. Slightly higher effects were, however, observed in the MF sample likely due to disinfection by chloramination of the membrane to avoid biofouling. ${ }^{10}$ On the next level of hierarchical clustering, the two WWTP effluents Eff1 + MF and Eff2 showed high similarity.

The largest separation was observed between the cluster of Eff1 + Eff2 + MF and all other samples (Figure 3), clearly demonstrating that cell-based bioassays can distinguish between wastewater and reclaimed water samples.

The bioanalytical fingerprints can also help distinguish between different water types: WWTP effluents not only showed the highest effects but also distinct responses related to known environmental pollutants, including pesticides, industrial chemicals, pharmaceuticals, and personal care products, for example, the activation of the aryl hydrocarbon receptor by PAHs or methylmercaptoaniline, ${ }^{23}$ the activation of the estrogen receptor by natural hormones and xenoestrogens, the activation of the glucocorticoid receptor by dexamethasone and organotin compounds, ${ }^{24}$ or photosynthesis inhibition by herbicides. The specific effects, caused by chemicals that bind to receptors, were decreased substantially in the WRPs.

Stormwater had a slightly different pattern to WWTP effluents but was also dominated by pesticides, as represented for example by herbicidal activity that was absent in other samples of its cluster. 
In other studies on stormwater one could even identify sewer cross-contamination by bioanalytical profiling. ${ }^{16}$

In contrast, disinfection by chlorination lead to disinfection byproducts, which showed distinct bioassay response patterns with clearly increased genotoxicity and oxidative stress responses in DW as compared to its source water (RW), while specific-receptor mediated effects were low in RW and almost fully disappeared in DW (Figure 3). This is consistent with previous bioanalytical profiling of the drinking water treatment process. ${ }^{15}$

\section{DISCUSSION}

Multiplexed Assays As a Screening Tool. The FACTORIAL assay was applied here for the first time to water samples and yielded interesting fingerprints of effects that were consistent with the results of the other bioassays. However, more work is required to implement reference chemicals and include a more rigorous dose-response assessment. The effect fingerprints were qualitatively consistent with responses seen in the initial ToxCast I screening of 320 pesticides, where $73 \%$ of the pesticides were responsive in PXR, 52\% in Nrf2/ARE and 46\% in PPAR $\gamma{ }^{9}$

Benchmarking Water Quality. A detailed discussion of the responses of each bioassay is provided in the SI, Section S6. Here follows a summary of the responsive and nonresponsive endpoints in relation to the associated step in the toxicity pathway (Table 2). It should be noted that, although responsiveness is related to assay sensitivity, even the most sensitive assay will not respond in the absence of chemicals capable of activating the bioassay endpoint. In other words, the absence of a measurable effect does not necessarily prove an assay insufficiently sensitive. Relative assay sensitivity can be assessed by comparing the effect concentrations and limits of detection of reference chemicals between assays. While such comparison was not possible for all assays tested in the present study, the results obtained can give some indication regarding the suitability of bioassays for monitoring purposes.

Induction of Xenobiotic Metabolism Pathways. Induction of metabolic pathways is not per se an indicator of toxicity but gives an indication of exposure to bioactive chemicals. Metabolism can detoxify or bioactivate chemicals. Omiecinski et $\mathrm{al}^{25}$ stressed the relevance and the toxicological implications of a number of xenobiotic metabolism pathways and associated NR, including the PXR, PPAR $\alpha, \beta$ and $\gamma, \mathrm{AhR}$, and CAR.

Three and six bioassays were evaluated for the PXR and AhR, respectively, and all showed positive responses in less treated samples and negative responses in recycled water and the blank (Table 2, SI, Section S6-A, Figure S5).

CAR plays a role in both phase I and II metabolism and plays a protective role against toxicity induced by bile acids as well as regulation of physiological functions. The target chemicals for CAR are less clearly defined than for AhR and while a few pesticides (e.g., methoxychlor, carbaryl propazine, 6-deisopropylatrazine) induced the CAR in the CAR-trans-FACTORIAL assay in previous work, ${ }^{9}$ no response was detected in the water samples in the CAR-trans-FACTORIAL assay up to an REF of 4. In contrast, the CAR-yeast showed a response in all samples

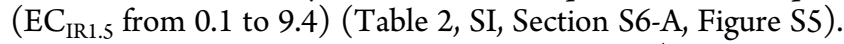

For PPAR, only two of seven bioassays (PPAR $\gamma$-transFACTORIAL and HELN-PPAR $\gamma$ ) gave signals in the four most polluted samples (Table 2, SI, Section S6-A, Figure S5). PPAR is strongly linked to the regulation of glucose and lipid metabolism as well as inflammation, and is less important for xenobiotic metabolism. ${ }^{26}$ In a high throughput study of 3000 environmentally relevant chemicals, roughly $1 \%$ of the tested chemicals were PPAR $\gamma$ agonists and $8 \%$ were PPAR $\gamma$ antagonists. $^{27}$ Organotins ${ }^{28}$ and polyhalogenated bisphenol $\mathrm{A}^{29}$ were found to induce $\operatorname{PPAR} \alpha$ and $\gamma$. The higher activity of $\operatorname{PPAR} \gamma$ over $\operatorname{PPAR} \alpha$ for water samples is consistent with the finding that 146 of 309 ToxCast phase I chemicals were active in PPAR $\gamma$-transFACTORIAL, while the other isoforms were less responsive. 9

Specific Modes of Toxic Action. Most specific modes of action involve binding to receptors or inhibition of enzymes. In the past, direct enzyme inhibition assays have been popular tools for water quality testing. Recent work on the influence of dissolved organic matter (DOM) on the acetylcholinesterase assay has demonstrated that DOM nonspecifically impacts the assay at relatively low concentrations. ${ }^{30}$ The implication of these findings is that for most tests with naked enzymes, water samples cannot be concentrated above a REF of 2 . In the present study, only the two wastewater samples produced a valid response in this assay. Despite the high relevance of this biological endpoint for many insecticides, it thus proves unsuitable to investigate recycled water samples.

Photosynthesis Inhibition. An important group of environmental contaminants are herbicides that inhibit photosynthesis. While they are specifically designed to target photosynthesis inhibition, herbicides can nevertheless be toxic to humans and are regulated in recycled and drinking water guidelines. The most sensitive species to detect herbicides are algae, for which the inhibition of photosystem II by triazines and phenylurea herbicides can be specifically measured by pulse-amplitude modulated fluorometry. ${ }^{31}$ This endpoint was very responsive in the water samples Eff1, Eff2, MF, SW that were suspected to contain herbicides (SI, Table S5).

Estrogen Receptor. The most relevant receptor-mediated effects are related to endocrine disruption (SI, Section S6-B, Figure S6). Estrogenic effects are by far the most prominent and environmentally relevant endocrine effects for aquatic species but they are overshadowed by other endocrine end points when it comes to human health. Fourteen different bioassays indicative of estrogenic effects were evaluated and all were active in four to five samples (Table 2). The absolute responsiveness was highest for ER-CALUX and MCF7-ERE but the effect pattern across the different samples was similar for all bioassays (SI, Table S5). No antiestrogenic activity could be detected in any of the samples, which is typical for samples that contain estrogenic chemicals. ${ }^{17}$

Androgen Receptor. Of seven bioassays (bioassay nos. 37-43, Table 1), only the MDA-kb2 produced positive results in the wastewater samples. Both GR and AR are expressed in this cell line and they share the same DNA response element, so it is unclear if the activity in this assay is purely AR-mediated, although incubation with flutamide indicates that the contribution of AR to the overall effect is higher than of GR.

Both bioassays for antiandrogenicity (anti-AR-CALUX and anti-MDA-kb2) were positive in some samples although only at very high REF. The WWTP effluents, which typically have highest antiandrogenic effects, were not responsive in antiMDA-kb2, presumably due to the interfering agonistic response of effluent, similar to what has been observed with YAS and anti-YAS in an earlier study. ${ }^{32}$

Progesterone Receptor. The two transactivation assays for the PR, PR-CALUX, and PR-GeneBLAzer, did not exceed the $10 \%$ effect threshold in all samples. However, progestagenic activity has been detected previously in aquatic samples. ${ }^{17,33,34}$ The anti-PR (anti-PR-CALUX) assay was also negative with samples tested to a REF of 2 . The increased levels of progesterone and $17 \alpha$-hydroxyprogesterone in the H295R bioassay 
for steroidogenesis were most likely due to an inhibitory effect on CYP21A.

Glucocorticoid Receptor. ER, AR, and PR are important for the development and functioning of the reproductive system. The GR is more abundant and found in all cell types. Given that the GR has important functions in glucose metabolism and the immune feedback mechanisms, it has been linked to a wide spectrum of diseases, including cardiovascular, inflammatory and immune disease, diabetes, and obesity, and is therefore of high potential relevance. Five bioassays targeting activation of the GR were included in this study, all of which were active in one or more samples (SI, Figure S7). The observed GR activity is in agreement with previous studies on similar water types. ${ }^{17,33}$

Thyroid Receptor. No assay indicative of modulation of the thyroid hormone system showed response to any of the water samples (SI, Table S5), which comes as no surprise because the most commonly observed thyroid agonists and goitrogens are oxyanions such as the perchlorate and nitrate. ${ }^{35}$ These inorganic ions do not act via TR binding and are not extracted with SPE.

RAR/RXR. The retinoic acid signaling pathway is crucial for reproduction and development as well as for cell homeostasis and immune function. ${ }^{36}$ Two receptors are key to this pathway, the retinoic acid receptor (RAR) and the retinoic $X$ receptor (RXR). RXR is a heterodimer partner not only for the RAR but also for other nuclear receptors including PPAR, PXR, CAR, and $\mathrm{TR}^{37}$

We tested four bioassays that are connected to the retinoic acid-signaling pathway but only the two-hybrid assay, where $\operatorname{RAR} \gamma$ is inserted into yeast with lacZ as reporter gene, showed activity in three samples. The ROR $\beta$-transFACTORIAL did not show any response with the water samples tested, although this endpoint tested positive in $30 \%$ of the ToxCast I chemicals. ${ }^{9}$ Clearly, the role of RXR for water quality assessment should be further explored in the future.

Reactive Toxicity. Testing for reactive toxicity focused on genotoxicity and mutagenicity (Table 2, SI Figure S8). Only one bioassay, the micronucleus assay, detects DNA damage directly; the Ames test relies on reverse mutations and the umuC assay on detection of DNA repair. Three samples were active in the micronucleus assay, Eff2, RW and DW (SI, Figure S8). The SOS chromotest and umuC assays gave consistent results and were responsive at lower REFs but the Ames assay gave more variable responses and even false-positive responses (presumably due to the high inherent degree of endogenous gene mutation in bacteria).

Tests for genotoxicity can be run in the presence and absence of a rat liver metabolic enzyme mix ( $S 9$ fraction) to differentiate between chemicals that require metabolic activation and those that are detoxified by metabolism. In the umuC and the Ames assay, there was no discernible difference between response with and without S9.

The E. coli assay for protein damage relies on growth inhibition differences between a strain that is glutathione-deficient (GSH-) and the corresponding parent strain (GSH+). ${ }^{38,39}$ These assays were found to be unsuitable for samples with high organic matter content. ${ }^{38}$ In the present study no effects could be detected although there appeared to be a qualitative difference in growth inhibition between the GSH- and the GSH+ strains.

Only one assay attempted to quantify reactive oxygen species formation in RTG2 cells and results were positive and consistent with the activation of oxidative stress response pathway discussed below.

Induction of Adaptive Stress Response Pathways. Both the heat shock response and the hypoxia induction were negative in all assays tested (SI, Table S5). No bioassay for endoplasmic reticulum stress could be identified and therefore this potentially relevant endpoint had to be omitted.

Response to inflammation was tested by enzyme-linked immunosorbent assay (ELISA) in the human T-lymphoblast cell line Jurkat E6.1 by quantifying $\mathrm{I} \kappa \mathrm{B}$, which is a chaperone for NF- $\kappa \mathrm{B}$ that keeps NF- $\kappa \mathrm{B}$ inactive and prevents it from entering the nucleus. Five samples tested positive in this assay (SI, Table S5). In contrast, the NF- $\kappa$ B-CALUX, NF- $\kappa \mathrm{B}-$ GeneBLAzer and the NF- $\kappa$ B-cisFACTORIAL did not respond to any of the samples. These latter assays are relatively new, have not yet been applied for water quality assessment and possibly require further validation work to improve their detection limits.

Three of four bioassays indicative of the oxidative stress response were active in six to eight samples, highlighting the potential importance of this stress response pathway. The AREc32, Nrf2/ARE-cisFACTORIAL and the Nrf2-CALUX were all able to detect effects at low sample enrichment. The data also showed a wide dynamic range between different samples, which makes them ideal water quality indicators, although their relevance to health effects is less evident than for other bioassays.

The p53 protein plays an important role as a tumor suppression factor but all evaluated assays did not show any effect, both, in presence and absence of S9.

General Cytotoxicity and Models for System Response. The overarching effect overlying each of the cellular toxicity pathways is cytotoxicity (Figure 1). As cytotoxicity normally manifests at higher concentrations than induction of response pathways, this endpoint is best implemented as a quality control measure for all induction assays to verify that cell vitality is not adversely affected. We did not complete full dose-response curves for cytotoxicity in all mammalian reporter gene assays apart from AREc32 for which cytotoxicity was similar to the targeted cytotoxicity assays in a human colon cancer cell line Caco 2 NRU. The fish cell line RTG2 was of relatively low responsiveness. Acute toxicity in the zebrafish embryo (DART 48h lethality) was only observed in two samples Eff2 and SW but at high enrichment factors (REF 5-6).

Cytotoxicity assays may also give information about system toxicity if appropriate cell lines are used, although a recent report by the ACuteTox project suggests little difference in response using different cell lines in vitro. ${ }^{40}$ Here we considered the sublethal endpoint in the zebrafish embryo toxicity test after $120 \mathrm{~h}$ of incubation as an indicator of developmental and potentially long-term apical effects. This effect was clearly more responsive than the $48 \mathrm{~h}$ acute lethality endpoint in the zebrafish embryo.

The SK-N-SH neuroblastoma cell $\operatorname{line}^{41}$ is sensitive to chemicals that block the sodium channels and similar cell lines have been used previously in an assay to evaluate paralytic shellfish poisons caused by neurotoxic freshwater cyanobacteria. ${ }^{42}$ We used a simpler version of this assay in this study, evaluating cytotoxicity as a coarse measure of cellular neurotoxicity. This endpoint was not active for our water samples tested to a REF of 2 .

Expression of various cytokines in the human acute monocytic leukemia cell line THP-1 gives an indication of potential immunotoxicity. ${ }^{17}$ Although a previous study reported 
detectable inhibition of $\operatorname{IL} 1 \beta$ secretion in chlorinated waters, ${ }^{17}$ we did not observe detectable effects in our study up to a REF of 2 .

Benchmarking Treatment Efficacy. The bioassay results can be used to assess and monitor treatment processes (see SI, Section S7 for more detail). Best suited for this purpose are bioassays that show a clear decrease in response with increasing treatment and will not fall below the detection limit after treatment. We refer to these assays as "indicator bioassays" from hereon. Reverse osmosis (RO) is known as highly efficient in removing trace constituents, and only 13 indicator bioassays remained above detection limit after RO (but below LOD after AO, SI, Figure S10). After ozonation and BAC treatment, (another) 13 indicator bioassays remained above detection limit (SI, Figures S11 and S12). Between the two water reclamation plants, 18 suitable indicator bioassays were identified, including those indicative of AhR, PXR, CAR, ER, algal toxicity, genotoxicity and oxidative stress (SI, Figures S11 and S12).

In contrast, chlorination and chloramination increased the response in 15 of the 101 bioassays in drinking water samples (SI, Figure S13). The increased effect was most pronounced in the induction of xenobiotic metabolism and the reactive modes of action and oxidative stress response, which is consistent with the formation of chlorinated disinfection byproducts that cause genotoxicity and oxidative stress. ${ }^{15,43}$ This comparison demonstrates that there is no single battery of bioassays that can be applied universally, but rather that a panel of assays should be tailored to fit the needs of each application.

A Routine Test Battery of Indicator Bioassays. Because a single bioassay is not capable of assessing water quality comprehensively, a set of relevant biological endpoints that are sensitive to micropollutants typically encountered in water samples can be used collectively as indicators of water quality. A battery of bioassays should include integrative endpoints such as cytotoxicity as well as endpoints specific to relevant steps in the cellular toxicity pathway. As a minimum, indicator bioassays should cover examples found responsive to and representative of "induction of xenobiotic metabolism", "endocrine disruption" and "adaptive stress responses". Relevant endpoints are proposed in the following:

1. Induction of xenobiotic metabolism. Our results confirmed that activation of the aryl hydrocarbon receptor, already one of the most widely applied endpoints in water quality assessment, is a relevant indicator of the presence of chemicals and should be included in any routine test battery. The pregnane $\mathrm{X}$ receptor showed high responsiveness to water samples and responds to a wide range of chemicals and should be further explored for routine application.

2. Endocrine disruption. Specific receptor-mediated modes of action including estrogenic and androgenic effects showed the most promise for routine water quality screening applications. Recent work using GR-CALUX applied to various environmental chemicals and water samples $^{33}$ also support our findings that GR activity is present and could be detected in secondary treated effluent with the current battery of GR bioassays. In addition, given the co-occurrence of progestins and synthetic estrogens in hormone replacement therapy, PR activity remains of interest, despite the negative findings here. Lastly, it is vital to test for antagonistic as well as agonistic effects.

3. Reactive modes of action. Genotoxicity as measured by well-established bioassays such as umuC or SOS chromotest served the purpose well. Bioassays derived from mammalian cells would be more relevant for human health and thus preferable to bacterial assays. As the p53 assays did not show the hoped-for responsiveness it is recommended to further evaluate alternative bioassays.

4. Adaptive stress response pathways. Oxidative stress response appears to be a highly sensitive and yet selective indicator of environmental pollution that responds to a wide range of chemicals as well as to transformation products and disinfection byproducts. ${ }^{44}$ This is consistent with previous chemical testing in Nrf2/ ARE-cisFACTORIAL, where almost $50 \%$ of the ToxCast chemicals were active. ${ }^{9}$ Thus this mode of action is recommended to be included in any routine test battery, especially if transformation reactions are expected.

5. Cytotoxicity and systemic response. The bacterial cytotoxicity assays ( $V$. fischeri and P. phosphoreum) are very fast and sensitive screening assays but their high sensitivity and effects caused by controls indicated that the responses may not be of human health relevance. In contrast, cytotoxicity assays with mammalian cells are comparatively less sensitive and clearly the bioassays for toxicity pathways are more relevant. With limitations, specific cell lines may be used as indicators of organ/ systemic response. Nevertheless, further work has to be invested in the selection of appropriate tests systems and protocols for cell-based bioassays for organ/systemic responses as these are much less developed than nonspecific cytotoxicity assays and bioassays targeting cellular toxicity pathways. The enzymatic AChE inhibition assay to test for one aspect of neurotoxicity failed completely but there is the potential to implement neurotoxicity endpoints in the zebrafish embryo toxicity test. $^{45} \mathrm{~A}$ whole organism in vitro assay, such as the zebrafish embryo assay may help to link specific responses from the cellular assays to systemic responses by the observed phenotypes.

We also recommend that more attention be paid to the basal activities of cell lines in use. As metabolism is the most crucial modifier of toxicity, detoxifying many chemicals but activating others, the metabolic capacity of bioassay cell lines needs to be considered when selecting or designing a bioassay. Many available cell lines have low metabolic activity and for these it is advisable to run each experiment in parallel in the presence of an exogenous metabolic mixture, for example, liver $S 9$ fraction.

In summary, an ideal battery of bioassays for water quality assessment and testing should contain sensitive bioassays that cover a wide range of cellular toxicity pathways (Figure 1). For induction of xenobiotic metabolism pathways, we recommend AhR and PXR. For specific modes of action, the receptormediated hormonal effects related to the estrogenic, glucocorticoid and antiandrogenic pathways appear to be most relevant as most are responsive to water samples. The oxidative stress response clearly stands out as a highly responsive defense mechanism. Cell viability ("cytotoxicity") assays should be further developed with a focus on those representative of systemic responses. 


\section{ASSOCIATED CONTENT}

\section{S Supporting Information}

Additional information on the water samples, the bioassay methods, the data evaluation, initial screening, bioassay results (including a large table with all detailed results), and a text on monitoring the treatment efficacy at WRPs is available free of charge via the Internet at http://pubs.acs.org.

\section{AUTHOR INFORMATION}

\section{Corresponding Author}

*(B.I.E.) Phone +61 73274 9180; fax: +61 73274 9003; e-mail: b.escher@uq.edu.au.

\section{Present Address}

\University of California Davis, Department of Environmental Toxicology, One Shields Avenue, Davis, California 956168588, United States.

\section{Author Contributions}

The manuscript was written through contributions of all authors. All authors have given approval to the final version of the manuscript.

\section{Notes}

The authors declare the following competing financial interest(s): Attagene and BDS are companies that market the bioassays applied by them in the present study.

\section{ACKNOWLEDGMENTS}

We thank Unitywater and Seqwater for access to their treatment plants. We acknowledge J.P. Giesy of University of Saskatchewan, Canada, for sharing the H4IIE-luc cells with RECETOX and M. Denison from University of California, Davis, U.S. for sharing the AhR-CAFLUX used at UQ and RECETOX. AREc32 cells were kindly provided by C.R. Wolf from University of Dundee, UK, to U.Q. We thank Michael Bartkow for helpful discussions, Peta Neale, Julien Reungoat, and Jatinder Sidhu for sampling assistance and Daniela Baumberger, Mriga Dutt, Eva Glenn, Ling Jin, and Shane McCarty for experimental assistance. This work was supported, mainly, by the WateReuse Research Foundation (WRF 10-07), and, in part, by the California Water Resources Control Board (Agreement No. 10-096-250) and the European Union, project Demeau, grant agreement number 308339.

\section{ABBREVIATIONS}

\begin{tabular}{|c|c|}
\hline $\mathrm{AO}$ & advanced oxidation \\
\hline AR & androgen receptor \\
\hline ASR & adaptive stress response \\
\hline ATG & Attagene \\
\hline AWQC & Australian Water Quality Centre \\
\hline BDS & BioDetection Systems \\
\hline BEQ & bioanalytical equivalent concentration \\
\hline CAPIM & $\begin{array}{l}\text { Centre for Aquatic Pollution Identification and } \\
\text { Management }\end{array}$ \\
\hline CAR & constitutive androstane receptor \\
\hline CSIRO & $\begin{array}{l}\text { Commonwealth Scientific and Industrial Research } \\
\text { Organisation }\end{array}$ \\
\hline $\mathrm{CT}$ & cytotoxicity \\
\hline CYP & cytochrome P450 monoxygenase \\
\hline DART & embryo toxicity test with the zebrafish Danio rerio \\
\hline DW & drinking water \\
\hline EC & effect concentration \\
\hline EEQ & estradiol equivalent concentration \\
\hline Eff & effluent \\
\hline
\end{tabular}

ER

GU

GR

$\mathrm{HK}$

HTS

IR

IRCM

ISO

IWW

MF

MOA

MTT

NJU

$\mathrm{NIH}$

NRU

OECD

PPAR

PR

PXR

RAR

RCEES Research Center for Eco-Environmental Sciences

RECETOX Research Centre for Toxic Compounds in the Environment

REF relative enrichment factor

RFU relative fluorescence units

RLU relative light units

RO reverse osmosis

ROS reactive oxygen species

RT-PCR real-time polymerase chain reaction

RW river water

SCCWRP Southern California Coastal Water Research Project

SPE

SW

SWISS

TEQ

UA

UCR

UF

UFZ

UQ

USF

WRP

WWTP

$\mathrm{XM}$ solid phase extraction

stormwater

Swiss Centre for Applied Ecotoxicology

toxic equivalent concentration

University of Arizona

University of California Riverside

University of Florida

Helmholtz Centre for Environmental Research

The University of Queensland

University of South Florida

water reclamation plant

wastewater treatment plant

xenobiotic metabolism

\section{REFERENCES}

(1) NRC. Toxicity Testing in the 21st Century: A Vision and a Strategy. Report in Brief.; National Research Council (NRC): Washington, D.C., 2007.

(2) Kavlock, R.; Chandler, K.; Houck, K.; Hunter, S.; Judson, R; Kleinstreuer, N.; Knudsen, T.; Martin, M.; Padilla, S.; Reif, D.; Richard, A.; Rotroff, D.; Sipes, N.; Dix, D. Update on EPA's ToxCast Program: Providing high throughput decision support tools for chemical risk management. Chem. Res. Toxicol. 2012, 25 (7), 12871302 .

(3) van der Burg, B.; Kroese, E. D.; Piersma, A. H. Towards a pragmatic alternative testing strategy for the detection of reproductive toxicants. Reprod. Toxicol. 2011, 31 (4), 558-561.

(4) Escher, B.; Leusch, F. Bioanalytical Tools in Water Quality Assessment.; IWA Publishing: London, UK, 2012. 
(5) Collins, F.; Gray, G. N.; Bucher, J. R. Transforming environmental health protection. Science 2008, 319, 906-907.

(6) Gohlke, J. M.; Portier, C. J. The forest for the trees: A systems approach to human health research. Environ. Health Perspect. 2007, $115,1261-1263$.

(7) Judson, R.; Kavlock, R.; Martin, M.; Reif, D.; Houck, K.; Knudsen, T.; Richard, A.; Tice, R. R.; Whelan, M.; Xia, M.; Huang, R.; Austin, C.; Daston, G.; Hartung, T.; Fowle, J. R., III; Wooge, W.; Tong, W.; Dix, D. Perspectives on validation of high-throughput assays supporting 21st century toxicity testing. ALTEX 2013, 30 (1), 51-66. (8) Tice, R. R.; Austin, C. P.; Kavlock, R.; Bucher, J. R. Improving the human hazard characterization of chemicals: A Tox21 update. Environ. Health Perspect. 2013, 121, 756-765.

(9) Martin, M. T.; Dix, D. J.; Judson, R. S.; Kavlock, R. J.; Reif, D. M.; Richard, A. M.; Rotroff, D. M.; Romanov, S.; Medvedev, A.; Poltoratskaya, N.; Gambarian, M.; Moeser, M.; Makarov, S. S.; Houck, K. A. Impact of environmental chemicals on key transcription regulators and correlation to toxicity endpoints within EPA's ToxCast program. Chem. Res. Toxicol. 2010, 23 (3), 578-590.

(10) Macova, M.; Toze, S.; Hodgers, L.; Mueller, J. F.; Bartkow, M. E.; Escher, B. I. Bioanalytical tools for the evaluation of organic micropollutants during sewage treatment, water recycling and drinking water generation. Water Res. 2011, 45 (14), 4238-4247.

(11) Escher, B. I.; Lawrence, M.; Macova, M.; Mueller, J. F.; Poussade, Y.; Robillot, C.; Roux, A.; Gernjak, W. Evaluation of contaminant removal of reverse osmosis and advanced oxidation in full-scale operation by combining passive sampling with chemical analysis and bioanalytical tools. Environ. Sci. Technol. 2011, 45 (12), 5387-5394.

(12) Reungoat, J.; Escher, B. I.; Macova, M.; Argaud, F. X.; Gernjak, W.; Keller, J. Ozonation and biological activated carbon filtration of wastewater treatment plant effluents. Water Res. 2012, 46 (3), 863872.

(13) Reungoat, J.; Escher, B. I.; Macova, M.; Keller, J. Biofiltration of wastewater treatment plant effluent: Effective removal of pharmaceuticals and personal care products and reduction of toxicity. Water Res. 2011, 45 (9), 2751-2762.

(14) Reungoat, J.; Macova, M.; Escher, B. I.; Carswell, S.; Mueller, J. F.; Keller, J. Removal of micropollutants and reduction of biological activity in a full scale reclamation plant using ozonation and activated carbon filtration. Water Res. 2010, 44 (2), 625-637.

(15) Neale, P. A.; Antony, A.; Bartkow, M.; Farre, M.; Heitz, A.; Kristiana, I.; Tang, J. Y. M.; Escher, B. I. Bioanalytical assessment of the formation of disinfection by-products in a drinking water treatment plant. Environ. Sci. Technol. 2012, 46 (18), 10317-10325.

(16) Tang, J. Y. M.; Glenn, E.; Aryal, R.; Gernjak, W.; Escher, B. I. Toxicity characterization of urban stormwater with bioanalytical tools. Water Res. 2013, 47 (15), 5594-5606.

(17) Leusch, F. D. L.; Khan, S. J.; Laingam, S.; Prochazka, E.; Trinh, T.; Froscio, S.; Chapman, H.; Humpage, A., Assessment of the application of bioanalytical tools as surrogate measure of chemical contaminants in recycled water. Water Res. 2014, 49 (1), 300-315.

(18) Tang, J. Y. M.; McCarty, S.; Glenn, E.; Neale, P. A.; Warne, M. S.; Escher, B. I. Mixture effects of organic micropollutants present in water: Towards the development of effect-based water quality trigger values for baseline toxicity. Water Res. 2013, 47 (10), 3300-3314.

(19) Strähle, U.; Scholz, S.; Geisler, R.; Greiner, P.; Hollert, H.; Rastegar, S.; Schumacher, A.; Selderslaghs, I.; Weiss, C.; Witters, H.; Braunbeck, T. Zebrafish embryos as an alternative to animal experiments-A commentary on the definition of the onset of protected life stages in animal welfare regulations. Reprod. Toxicol. 2012, 33 (2), $128-132$.

(20) Seo, J. B.; Moon, H. M.; Kim, W. S.; Lee, Y. S.; Jeong, H. W.; Yoo, E. J.; Ham, J. Y.; Kang, H. J.; Park, M. G.; Steffensen, K. R.; Stulnig, T. M.; Gustafsson, J. A.; Dai Park, S.; Kim, J. B. Activated liver $\mathrm{X}$ receptors stimulate adipocyte differentiation through induction of peroxisome proliferator-activated receptor gamma expression. Mol. Cell. Biol. 2004, 24 (8), 3430-3444.
(21) Janesick, A.; Blumberg, B. Minireview: PPAR gamma as the target of obesogens. J. Steroid Biochem. Mol. Biol. 2011, 127 (1-2), 48.

(22) Neale, P. A.; Escher, B. I., Does dissolved organic carbon cause artefacts in cell-based bioassays? Chemosphere 2013, submitted 25 July 2013.

(23) Denison, M. S.; Nagy, S. R. Activation of the aryl hydrocarbon receptor by structurally diverse exogenous and endogenous chemicals. Annu. Rev. Pharmacol. Toxicol. 2003, 43, 309-334.

(24) Odermatt, A.; Gumy, C.; Atanasov, A. G.; Dzyakanchuk, A. A. Disruption of glucocorticoid action by environmental chemicals: Potential mechanisms and relevance. J. Steroid Biochem. Mol. Biol. 2006, 102 (1-5), 222-231.

(25) Omiecinski, C. J.; Heuvel, J. P. V.; Perdew, G. H.; Peters, J. M. Xenobiotic metabolism, disposition, and regulation by receptors: From biochemical phenomenon to predictors of major toxicities. Toxicol. Sci. 2011, 120, S49-S75.

(26) Scarsi, M.; Podvinec, M.; Roth, A.; Hug, H.; Kersten, S.; Albrecht, H.; Schwede, T.; Meyer, U. A.; Rucker, C. Sulfonylureas and glinides exhibit peroxisome proliferator-activated receptor gamma activity: A combined virtual screening and biological assay approach. Mol. Pharmacol. 2007, 71 (2), 398-406.

(27) Huang, R. L.; Xia, M. H.; Cho, M. H.; Sakamuru, S.; Shinn, P.; Houck, K. A.; Dix, D. J.; Judson, R. S.; Witt, K. L.; Kavlock, R. J.; Tice, R. R.; Austin, C. P. Chemical genomics profiling of environmental chemical modulation of human nuclear receptors. Environ. Health Perspect. 2011, 119 (8), 1142-1148.

(28) le Maire, A.; Grimaldi, M.; Roecklin, D.; Dagnino, S.; VivatHannah, V.; Balaguer, P.; Bourguet, W. Activation of RXR-PPAR heterodimers by organotin environmental endocrine disruptors. EMBO Rep. 2009, 10 (4), 367-373.

(29) Riu, A.; Grimaldi, M.; le Maire, A.; Bey, G.; Phillips, K.; Boulahtouf, A.; Perdu, E.; Zalko, D.; Bourguet, W.; Balaguer, P. Peroxisome proliferator-activated receptor gamma is a target for halogenated analogs of bisphenol A. Environ. Health Perspect. 2011, 119 (9), 1227-1232.

(30) Neale, P. A.; Escher, B. I. Co-extracted dissolved organic carbon has a suppressive effect on the acetylcholinesterase inhibition assay. Environ. Toxicol. Chem. 2013, 32 (7), 1526-1534.

(31) Muller, R.; Schreiber, U.; Escher, B. I.; Quayle, P.; Nash, S. M. B.; Mueller, J. F. Rapid exposure assessment of PSII herbicides in surface water using a novel chlorophyll a fluorescence imaging assay. Sci. Total Environ. 2008, 401 (1-3), 51-59.

(32) Stalter, D.; Magdeburg, A.; Wagner, M.; Oehlmann, J. Ozonation and activated carbon treatment of sewage effluents: Removal of endocrine activity and cytotoxicity. Water Res. 2011, 45 (3), $1015-1024$.

(33) Van der Linden, S. C.; Heringa, M. B.; Man, H. Y.; Sonneveld, E.; Puijker, L. M.; Brouwer, A.; Van der Burg, B. Detection of multiple hormonal activities in wastewater effluents and surface water, using a panel of steroid receptor CALUX bioassays. Environ. Sci. Technol. 2008, 42 (15), 5814-5820.

(34) Schriks, M.; van der Linden, S. C.; Stoks, P. G. M.; van der Burg, B.; Puijker, L.; de Voogt, P.; Heringa, M. B. Occurrence of glucocorticogenic activity in various surface waters in The Netherlands. Chemosphere 2013, 93 (2), 450-454.

(35) Bruce, G. M.; Corey, L. M.; Mandel, J. H.; Pleus, R. C. Urinary nitrate, thiocyanate, and perchlorate and serum thyroid endpoints based on NHANES 2001 to 2002. J. Occup. Environ. Med. 2013, 55 (1), 64-70.

(36) Novák, J.; Benísek, M.; Hilscherová, K. Disruption of retinoid transport, metabolism and signaling by environmental pollutants. Environ. Int. 2008, 34 (6), 898-913.

(37) Lefebvre, P.; Benomar, Y.; Staels, B. Retinoid X receptors: Common heterodimerization partners with distinct functions. Trends Endocrinol. Metab. 2010, 21 (11), 676-683.

(38) Tang, J. Y. M.; Glenn, E.; Thoen, H.; Escher, B. I. In vitro bioassay for reactive toxicity towards proteins implemented for water quality monitoring. J. Environ. Monit. 2012, 14, 1073-1081. 
(39) Escher, B. I.; Dutt, M.; Maylin, E.; Tang, J. Y. M.; Toze, S.; Wolf, C. R.; Lang, M. Water quality assessment using the AREc32 reporter gene assay indicative of the oxidative stress response pathway. $J$. Environ. Monit. 2012, 14, 2877-2885.

(40) Clothier, R.; Gomez-Lechon, M. J.; Kinsner-Ovaskainen, A.; Kopp-Schneider, A.; O'Connor, J. E.; Prieto, P.; Stanzel, S. Comparative analysis of eight cytotoxicity assays evaluated within the ACuteTox Project. Toxicol. Vitro 2013, 27 (4), 1347-1356.

(41) Ba, F.; Pang, P. K. T.; Benishin, C. G. The establishment of a reliable cytotoxic system with SK-N-SH neuroblastoma cell culture. J. Neurosci. Methods 2003, 123 (1), 11-22.

(42) Humpage, A. R.; Ledreux, A.; Fanok, S.; Bernard, C.; Briand, J. F.; Eaglesham, G.; Papageorgiou, J.; Nicholson, B.; Steffensen, D. Application of the neuroblastoma assay for paralytic shellfish poisons to neurotoxic freshwater cyanobacteria: Interlaboratory calibration and comparison with other methods of analysis. Environ. Toxicol. Chem. 2007, 26 (7), 1512-1519.

(43) Richardson, S. D.; Plewa, M. J.; Wagner, E. D.; Schoeny, R.; DeMarini, D. M. Occurrence, genotoxicity, and carcinogenicity of regulated and emerging disinfection by-products in drinking water: A review and roadmap for research. Mutat. Res. 2007, 636 (1-3), 178242.

(44) Escher, B. I.; van Daele, C.; Dutt, M.; Tang, J. Y. M.; Altenburger, R. Most oxidative stress response in water samples comes from unknown chemicals: The need for effect-based water quality trigger values. Environ. Sci. Technol. 2013, 47 (13), 7002-7011.

(45) Kokel, D.; Bryan, J.; Laggner, C.; White, R.; Cheung, C. Y. J.; Mateus, R.; Healey, D.; Kim, S.; Werdich, A. A.; Haggarty, S. J.; MacRae, C. A.; Shoichet, B.; Peterson, R. T. Rapid behavior-based identification of neuroactive small molecules in the zebrafish. Nat. Chem. Biol. 2010, 6 (3), 231-237.

(46) Romanov, S.; Medvedev, A.; Gambarian, M.; Poltoratskaya, N.; Moeser, M.; Medvedeva, L.; Diatchenko, L.; Makarov, S. Homogeneous reporter system enables quantitative functional assessment of multiple transcription factors. Nat. Methods 2008, 5 (3), 253-260.

(47) Lemaire, G.; Mnif, W.; Pascussi, J. M.; Pillon, A.; Rabenoelina, F.; Fenet, H.; Gomez, E.; Casellas, C.; Nicolas, J. C.; Cavailles, V.; Duchesne, M. J.; Balaguer, P. Identification of new human pregnane $\mathrm{X}$ receptor ligands among pesticides using a stable reporter cell system. Toxicol. Sci. 2006, 91 (2), 501-509.

(48) Creusot, N.; Kinani, S.; Balaguer, P.; Tapie, N.; LeMenach, K.; Maillot-Marechal, E.; Porcher, J. M.; Budzinski, H.; Ait-Aissa, S. Evaluation of an hPXR reporter gene assay for the detection of aquatic emerging pollutants: Screening of chemicals and application to water samples. Anal. Bioanal. Chem. 2010, 396 (2), 569-583.

(49) Shiraishi, F.; Shirashi, H.; Nishikawa, J.; Nishihara, T.; Morita, M. Development of a simple operational estrogenicity assay system using the yeast two-hybrid system. J. Environ. Chem. 2000, 10 (1), 57-64.

(50) Seimandi, M.; Lemaire, G.; Pillon, A.; Perrin, A.; Carlavan, I.; Voegel, J. J.; Vignon, F.; Nicolas, J. C.; Balaguer, P. Differential responses of PPAR alpha, PPAR delta, and PPAR gamma reporter cell lines to selective PPAR synthetic ligands. Anal. Biochem. 2005, 344 (1), $8-15$.

(51) Gijsbers, L.; van Eekelen, H. D. L. M.; de Haan, L. H. J.; Swier, J. M.; Heijink, N. L.; Kloet, S. K.; Man, H. Y.; Bovy, A. G.; Keijer, J.; Aarts, J. M. M. J. G.; van der Burg, B.; Rietjens, I. M. C. M. Induction of peroxisome proliferator-activated receptor gamma (PPAR gamma)mediated gene expression by tomato (Solanum lycopersicum L.) extracts. J. Agric. Food Chem. 2013, 61 (14), 3419-3427.

(52) Piersma, A. H.; Bosgra, S.; van Duursen, M. B. M.; Hermsen, S. A. B.; Jonker, L. R. A.; Kroese, E. D.; van der Linden, S. C.; Man, H.; Roelofs, M. J. E.; Schulpen, S. H. W.; Schwarz, M.; Uibel, F.; van VugtLussenburg, B. M. A.; Westerhout, J.; Wolterbeek, A. P. M.; van der Burg, B. Evaluation of an alternative in vitro test battery for detecting reproductive toxicants. Reprod. Toxicol. 2013, 38, 53-64.

(53) Gijsbers, L.; Man, H. Y.; Kloet, S. K.; de Haan, L. H.; Keijer, J.; Rietjens, I. M.; van der Burg, B.; Aarts, J. M. Stable reporter cell lines for peroxisome proliferator-activated receptor gamma
(PPARgamma)-mediated modulation of gene expression. Anal. Biochem. 2011, 414 (1), 77-83.

(54) Law, A. Y. S.; Wei, X.; Zhang, X. W.; Mak, N. K.; Cheung, K. C.; Wong, M. H.; Giesy, J. P.; Wong, C. K. C. Biological analysis of endocrine-disrupting chemicals in animal meats from the Pearl River Delta, China. J. Exposure Sci. Environ. Epidemiol. 2012, 22 (1), 93-100.

(55) EPA, U.S. Prioritization of the Endocrine Disruptor Screening Program Universe of Chemicals for an Estrogen Receptor Adverse Outcome Pathway Using Computational Toxicology Tools; U.S. Environmental Protection Agency: Washington, DC, 2012.

(56) Miller, C. A. A human aryl hydrocarbon receptor signaling pathway constructed in yeast displays additive responses to ligand mixtures. Toxicol. Appl. Pharmacol. 1999, 160 (3), 297-303.

(57) Kamata, R.; Shiraishi, F.; Nakajima, D.; Takigami, H.; Shiraishi, $\mathrm{H}$. Mono-hydroxylated polychlorinated biphenyls are potent aryl hydrocarbon receptor ligands in recombinant yeast cells. Toxicol. Vitro 2009, 23 (4), 736-743.

(58) Nagy, S. R.; Sanborn, J. R.; Hammock, B. D.; Denison, M. S. Development of a green fluorescent protein-based cell bioassay for the rapid and inexpensive detection and characterization of Ah receptor agonists. Toxicol. Sci. 2002, 65 (2), 200-210.

(59) Jarosova, B.; Blaha, L.; Vrana, B.; Randak, T.; Grabic, R.; Giesy, J. P.; Hilscherova, K. Changes in concentrations of hydrophilic organic contaminants and of endocrine-disrupting potential downstream of small communities located adjacent to headwaters. Environ. Int. 2012, $45,22-31$.

(60) Jin, L.; van Mourik, L.; Gaus, C.; Escher, B. Applicability of passive sampling to bioanalytical screening of bioaccumulative chemicals in marine wildlife. Environ. Sci. Technol. 2013, 47 (14), $7982-7988$.

(61) Sanderson, J. T.; Aarts, J.; Brouwer, A.; Froese, K. L.; Denison, M. S.; Giesy, J. P. Comparison of Ah receptor-mediated luciferase and ethoxyresorufin-O-deethylase induction in H4IIE cells: Implications for their use as bioanalytical tools for the detection of polyhalogenated aromatic hydrocarbons. Toxicol. Appl. Pharmacol. 1996, 137 (2), 316325.

(62) Weil, M.; Scholz, S.; Zimmer, M.; Sacher, F.; Duis, K. Gene expression analysis in zebrafish embryos: A potential approach to predict effect concentrations in the fish early life stage test. Environ. Toxicol. Chem. 2009, 28 (9), 1970-1978.

(63) Klüver, N.; Yang, L. X.; Busch, W.; Scheffler, K.; Renner, P.; Strähle, U.; Scholz, S., Transcriptional response of zebrafish embryos exposed to neurotoxic compounds reveals a muscle activity dependent hspb11 expression. PLoS One 2011, 6, (12).

(64) Escher, B. I.; Bramaz, N.; Mueller, J. F.; Quayle, P.; Rutishauser, S.; Vermeirssen, E. L. M. Toxic equivalent concentrations (TEQs) for baseline toxicity and specific modes of action as a tool to improve interpretation of ecotoxicity testing of environmental samples. $J$. Environ. Monitor 2008, 10 (5), 612-621.

(65) Ellman, G. L.; Courtney, K. D.; Andres, V., jr; Featherstone, R. $\mathrm{M}$. A new and rapid colorimetric determination of acetylcholinesterase activity. Biochem. Pharmacol. 1961, 7 (2), 88-90 IN1, 91-95.

(66) Sonneveld, E.; Jansen, H. J.; Riteco, J. A. C.; Brouwer, A.; van der Burg, B. Development of androgen- and estrogen-responsive bioassays, members of a panel of human cell line-based highly selective steroid-responsive bioassays. Toxicol. Sci. 2005, 83 (1), 136-148.

(67) Soto, A. M.; Sonnenschein, C.; Chung, K. L.; Fernandez, M. F.; Olea, N.; Serrano, F. O. The E-SCREEN assay as a tool to identify estrogens: An update on estrogenic environmental pollutants. Environ. Health Perspect. 1995, 103 (Suppl. 7), 113-122.

(68) Routledge, E. J.; Sumpter, J. P. Estrogenic activity of surfactants and some of their degradation products assessed using a recombinant yeast screen. Environ. Toxicol. Chem. 1996, 15 (3), 241-248.

(69) Escher, B. I.; Bramaz, N.; Quayle, P.; Rutishauser, S.; Vermeirssen, E. L. M. Monitoring of the ecotoxicological hazard potential by polar organic micropollutants in sewage treatment plants and surface waters using a mode-of-action based test battery. J. Environ. Monit. 2008, 10 (5), 622-631. 
(70) Allinson, M.; Shiraishi, F.; Allinson, G. A comparison of recombinant receptor-reporter gene bioassays and a total estrogen enzyme linked immunosorbent assay for the rapid screening of estrogenic activity in natural and waste waters. Bull. Environ. Contam. Toxicol. 2011, 86 (5), 461-464.

(71) Balaguer, P.; Francois, F.; Comunale, F.; Fenet, H.; Boussioux, A. M.; Pons, M.; Nicolas, J. C.; Casellas, C. Reporter cell lines to study the estrogenic effects of xenoestrogens. Sci. Total Environ. 1999, $233(1-3), 47-56$.

(72) Maggioni, S.; Balaguer, P.; Chiozzotto, C.; Benfenati, E. Screening of endocrine-disrupting phenols, herbicides, steroid estrogens, and estrogenicity in drinking water from the waterworks of 35 Italian cities and from PET-bottled mineral water. Environ. Sci. Pollut. Res. 2013, 20 (3), 1649-1660.

(73) Lemaire, G.; Mnif, W.; Mauvais, P.; Balaguer, P.; Rahmani, R. Activation of alpha- and beta-estrogen receptors by persistent pesticides in reporter cell lines. Life Sci. 2006, 79 (12), 1160-1169.

(74) OECD Test guideline 455. Stably Transfected Human Estrogen Receptor-A Transcriptional Activation Assay for Detection of Estrogenic Agonist-Activity of Chemicals, TG 305; Environmental Directorate; Organisation for Economic Co-operation and Development: Paris, France, 1984, 2009.

(75) Zhang, X. W.; Chang, H.; Wiseman, S.; He, Y. H.; Higley, E.; Jones, P.; Wong, C. K. C.; Al-Khedhairy, A.; Giesy, J. P.; Hecker, M. Bisphenol A disrupts steroidogenesis in human H295R cells. Toxicol. Sci. 2011, 121 (2), 320-327.

(76) He, Y. H.; Wiseman, S. B.; Hecker, M.; Zhang, X. W.; Wang, N.; Perez, L. A.; Jones, P. D.; El-Din, M. G.; Martin, J. W.; Giesy, J. P. Effect of ozonation on the estrogenicity and androgenicity of oil sands process-affected water. Environ. Sci. Technol. 2011, 45 (15), 62686274.

(77) Brion, F.; Le Page, Y.; Piccini, B.; Cardoso, O.; Tong, S. K.; Chung, B. C.; Kah, O., Screening estrogenic activities of chemicals or mixtures in vivo using transgenic (cyp19alb-GFP) zebrafish embryos. PLoS One 2012, 7, (5).

(78) van der Burg, B.; Winter, R.; Man, H. Y.; Vangenechten, C.; Berckmans, P.; Weimer, M.; Witters, H.; van der Linden, $S$. Optimization and prevalidation of the in vitro AR CALUX method to test androgenic and antiandrogenic activity of compounds. Reprod. Toxicol. 2010, 30 (1), 18-24.

(79) Molina-Molina, J. M.; Hillenweck, A.; Jouanin, I.; Zalko, D.; Cravedi, J. P.; Fernandez, M. F.; Pillon, A.; Nicolas, J. C.; Olea, N.; Balaguer, P. Steroid receptor profiling of vinclozolin and its primary metabolites. Toxicol. Appl. Pharmacol. 2006, 216 (1), 44-54.

(80) Delfosse, V.; Grimaldi, M.; Pons, J. L.; Boulahtouf, A.; le Maire, A.; Cavailles, V.; Labesse, G.; Bourguet, W.; Balaguer, P. Structural and mechanistic insights into bisphenols action provide guidelines for risk assessment and discovery of bisphenol A substitutes. Proc. Natl. Acad. Sci. U.S.A. 2012, 109 (37), 14930-14935.

(81) Sohoni, P.; Sumpter, J. Several environmental oestrogens are also anti-androgens. J. Endocrinol. 1998, 158 (3), 327-339.

(82) Thomas, K. V.; Hurst, M. R.; Matthiessen, P.; McHugh, M.; Smith, A.; Waldock, M. J. An assessment of in vitro androgenic activity and the identification of environmental androgens in United Kingdom estuaries. Environ. Toxicol. Chem. 2002, 21 (7), 1456-1461.

(83) Wilson, V. S.; Bobseine, K.; Lambright, C. R.; Gray, L. E. A novel cell line, MDA-kb2, that stably expresses an androgen- and glucocorticoid-responsive reporter for the detection of hormone receptor agonists and antagonists. Toxicol. Sci. 2002, 66 (1), 69-81.

(84) Pavlikova, N.; Blahova, L.; Klan, P.; Bathula, S. R.; Sklenar, V.; Giesy, J. P.; Blaha, L. Enantioselective effects of alpha-hexachlorocyclohexane $(\mathrm{HCH})$ isomers on androgen receptor activity in vitro. Chemosphere 2012, 86 (1), 65-69.

(85) Gutleb, A. C.; Meerts, I. A. T. M.; Bergsma, J. H.; Schriks, M.; Murk, A. J. T-Screen as a tool to identify thyroid hormone receptor active compounds. Environ. Toxicol. Pharmacol. 2005, 19 (2), 231238.

(86) Fini, J. B.; Riu, A.; Debrauwer, L.; Hillenweck, A.; Le Mevel, S.; Chevolleau, S.; Boulahtouf, A.; Palmier, K.; Balaguer, P.; Cravedi, J. P.;
Demeneix, B. A.; Zalko, D. Parallel biotransformation of tetrabromobisphenol a in Xenopus laevis and mammals: Xenopus as a model for endocrine perturbation studies. Toxicol. Sci. 2012, 125 (2), 359-367.

(87) Novak, J.; Benisek, M.; Pachernik, J.; Janosek, J.; Sidlova, T.; Kiviranta, H.; Verta, M.; Giesy, J. P.; Blaha, L.; Hilscherova, K. Interference of contaminated sediment extracts and environmental pollutants with retinoid signaling. Environ. Toxicol. Chem. 2007, 26 (8), $1591-1599$.

(88) Kamata, R.; Shiraishi, F.; Nishikawa, J.; Yonemoto, J.; Shiraishi, $\mathrm{H}$. Screening and detection of the in vitro agonistic activity of xenobiotics on the retinoic acid receptor. Toxicol. In Vitro 2008, 22 (4), 1050-1061.

(89) Oda, Y.; Nakamura, S.-I.; Oki, I.; Kato, T.; Shinagawa, H. Evaluation of the new system (umu-test) for the detection of environmental mutagens and carcinogens. Mutat. Res. 1985, 147 (5), 219-229.

(90) ISO13828, Water Quality-Determination of the Genotoxicity of Water and Waste Water Using the Umu-Test; International Organization for Standardization (ISO): Geneva, Switzerland, 1999.

(91) Oda, Y.; Yamazaki, H.; Thier, R.; Ketterer, B.; Guengerich, F. P.; Shimada, T. A new Salmonella typhimurium NM5004 strain expressing rat glutathione S-transferase 5-5: Use in detection of genotoxicity of dihaloalkanes using an SOS/umu test system. Carcinogenesis 1996, 17 (2), 297-302.

(92) Quillardet, P.; Huisman, O.; Dari, R.; Hofnung, M. SOS Chromotest, a direct assay of induction of an SOS function in Escherichia coli K-12 to measure genotoxicity. Proc. Natl. Acad. Sci. U.S.A. 1982, 79 (19), 5971-5975.

(93) Skarek, M.; Janosek, J.; Cupr, P.; Kohoutek, J.; NovotnaRychetska, A.; Holoubek, I. Evaluation of genotoxic and non-genotoxic effects of organic air pollution using in vitro bioassays. Environ. Int. 2007, 33 (7), 859-866.

(94) Ames, B. N.; McCann, J.; Yamasaki, E. Methods for detecting carcinogens and mutagens with the salmonella/mammalian-microsome mutagenicity test. Mutat. Res. 1975, 31 (6), 347-363.

(95) Umbuzeiro, G. D.; Rech, C. M.; Correia, S.; Bergamasco, A. M.; Cardenette, G. H. L.; Fluckiger-Isler, S.; Kamber, M. Comparison of the Salmonella/microsome microsuspension assay with the new microplate fluctuation protocol for testing the mutagenicity of environmental samples. Environ. Mol. Mutagen. 2010, 51 (1), 31-38.

(96) Richard, J. Toxicological in Vitro Evaluation of Organic Micropollutants before and after Oxidative Waste Water Treatment; Universität Duisburg-Essen: Essen, Germany, 2012; http:// duepublico.uni-duisburg-essen.de/servlets/DocumentServlet?id= 31124.

(97) Reifferscheid, G.; Maes, H. M.; Allner, B.; Badurova, J.; Belkin, S.; Bluhm, K.; Brauer, F.; Bressling, J.; Domeneghetti, S.; Elad, T.; Flückiger-Isler, S.; Grummt, H. J.; Gürtler, R.; Hecht, A.; Heringa, M. B.; Hollert, H.; Huber, S.; Kramer, M.; Magdeburg, A.; Ratte, H. T.; Sauerborn-Klobucar, R.; Sokolowski, A.; Soldan, P.; Smital, T.; Stalter, D.; Venier, P.; Ziemann, C.; Zipperle, J.; Buchinger, S. International round-robin study on the Ames fluctuation test. Environ. Mol. Mutagen. 2012, 53 (3), 185-197.

(98) Fenech, M.; Chang, W. P.; Kirsch-Volders, M.; Holland, N.; Bonassi, S.; Zeiger, E. HUMN project: Detailed description of the scoring criteria for the cytokinesis-block micronucleus assay using isolated human lymphocyte cultures. Mutat. Res. 2003, 534 (1-2), $65-75$.

(99) Laingam, S.; Froscio, S. M.; Humpage, A. R. Flow-cytometric analysis of in vitro micronucleus formation: Comparative studies with WIL2-NS human lymphoblastoid and L5178Y mouse lymphoma cell lines. Mutat. Res. 2008, 656 (1-2), 19-26.

(100) Rosenkranz, A. R.; Schmaldienst, S.; Stuhlmeier, K. M.; Chen, W. J.; Knapp, W.; Zlabinger, G. J. A microplate assay for the detection of oxidative products using $2^{\prime}, 7^{\prime}$-dichlorofluorescin-diacetate. $J$. Immunol. Meth. 1992, 156 (1), 39-45.

(101) Bain, P. A.; Schuller, K. A. Use of fluorogenic probes to differentiate between hydrophilic and lipophilic antioxidant activity in a fish cell line. J. Agric. Food Chem. 2012, 60 (3), 699-705. 
(102) Harder, A.; Escher, B. I.; Landini, P.; Tobler, N. B.; Schwarzenbach, R. P. Evaluation of bioanalytical tools for toxicity assessment and mode of toxic action classification of reactive chemicals. Environ. Sci. Technol. 2003, 37 (21), 4962-4970.

(103) Piersma, A. H. Alternative methods for developmental toxicity testing. Basic Clin. Pharmacol. Toxicol. 2006, 98 (5), 427-431.

(104) Wang, X. J.; Hayes, J. D.; Wolf, C. R. Generation of a stable antioxidant response element-driven reporter gene cell line and its use to show redox-dependent activation of Nrf2 by cancer chemotherapeutic agents. Cancer Res. 2006, 66 (22), 10983-10994.

(105) Villeneuve, N. F.; Du, Y.; Wang, X. J.; Sun, Z.; Zhang, D. D. High-throughput screening of chemopreventive compounds targeting Nrf2. In 3rd IEEE International Conference on Nano/Micro Engineered and Molecular Systems; IEEE: New York, NY, 2008; Vols 1-3, pp $1138-1141$.

(106) Van der Linden, S.; von Bergh, A.; Van Vugt-Lussenburg, B.; Jonker, L.; Brouwer, A.; Teunis, M.; Krul, C.; van der Burg,, B.; Development of a panel of high throughput reporter gene assays to 1343 detect genotoxicity and oxidative stress. Mutat. Res. 2013, in press, DOI: 10.1016/j.mrgentox.2013.09.009.

(107) Konsoula, R.; Barile, F. A. Correlation of in vitro cytotoxicity with paracellular permeability in Caco-2 cells. Toxicol. Vitro 2005, 19 (5), 675-684.

(108) Mosmann, T. Rapid colorimetric assay for cellular growth and survival: Application to proliferation and cytotoxicity assays. J. Immunol. Meth. 1983, 65 (1-2), 55-63.

(109) Küster, E.; Altenburger, R. Comparison of cholin- and carboxylesterase enzyme inhibition and visible effects in the zebra fish embryo bioassay under short-term paraoxon-methyl exposure. Biomarkers 2006, 11 (4), 341-354.

(110) Gündel, U.; Kalkhof, S.; Zitzkat, D.; von Bergen, M.; Altenburger, R.; Küster, E. Concentration-response concept in ecotoxicoproteomics: Effects of different phenanthrene concentrations to the zebrafish (Danio rerio) embryo proteome. Ecotox. Environ. Saf. 2012, 76, 11-22.

(111) Knöbel, M.; Busser, F. J. M.; Rico-Rico, A.; Kramer, N. I.; Hermens, J. L. M.; Hafner, C.; Tanneberger, K.; Schirmer, K.; Scholz, S. Predicting adult fish acute lethality with the zebrafish embryo: Relevance of test duration, endpoints, compound properties, and exposure concentration analysis. Environ. Sci. Technol. 2012, 46 (17), 9690-9700.

(112) Manger, R. L.; Leja, L. S.; Lee, S. Y.; Hungerford, J. M.; Hokama, Y.; Dickey, R. W.; Granade, H. R.; Lewis, R.; Yasumoto, T.; Wekell, M. M. Detection of paralytic shellfish poison by rapid cell bioassay: Antagonism of voltage-gated sodium channel active toxins in vitro. J. AOAC Int. 1995, 78 (2), 521-527.

(113) Baqui, A.; Meiller, T. F.; Chon, J. J.; Turng, B. F.; Falkler, W. A. Granulocyte-macrophage colony-stimulating factor amplification of interleukin-1 beta and tumor necrosis factor alpha production in THP1 human monocytic cells stimulated with lipopolysaccharide of oral microorganisms. Clin. Diagn. Lab. Immunol. 1998, 5 (3), 341-347.

(114) OECD. Test Guideline No. 201. Alga, Growth Inhibition Test; Environmental Directorate, Organisation for Economic Co-operation and Development: Paris, France, 1984.

(115) ISO11348-3. Water Quality-Determination of the Inhibitory Effect of Water Samples on the Light Emission of Vibrio Fischeri (Luminescent Bacteria Test); International Organization for Standardization (ISO): Geneva, Switzerland, 1998.

(116) GB/T 15441-1995 Water Quality-determination of the Acute Toxicity-Luminescent Bacteria Test; National Standard of China, 1995; ttp://kjs.mep.gov.cn/hjbhbz/bzwb/shjbh/sjcgfffbz/199508/ t19950801 67352.htm.

(117) Ankley, G. T.; Bennett, R. S.; Erickson, R. J.; Hoff, D. J.; Hornung, M. W.; Johnson, R. D.; Mount, D. R.; Nichols, J. W.; Russom, C. L.; Schmieder, P. K.; Serrrano, J. A.; Tietge, J. E.; Villeneuve, D. L. Adverse outcome pathways: A conceptual framework to support ecotoxicology research and risk assessment. Environ. Toxicol. Chem. 2010, 29 (3), 730-741. 